\title{
Mixotrophic chemosynthesis in a deep-sea anemone from hydrothermal vents in the Pescadero Basin, Gulf of California
}

\author{
Shana K. Goffredi ${ }^{1 *} \mathbb{D}$, Cambrie Motooka', David A. Fike ${ }^{2}$, Luciana C. Gusmão ${ }^{3}$, Ekin Tilic ${ }^{4}$, Greg W. Rouse ${ }^{5}$ and
} Estefanía Rodríguez ${ }^{3}$

\begin{abstract}
Background: Numerous deep-sea invertebrates, at both hydrothermal vents and methane seeps, have formed symbiotic associations with internal chemosynthetic bacteria in order to harness inorganic energy sources typically unavailable to animals. Despite success in nearly all marine habitats and their well-known associations with photosynthetic symbionts, Cnidaria remain one of the only phyla present in the deep-sea without a clearly documented example of dependence on chemosynthetic symbionts.

Results: A new chemosynthetic symbiosis between the sea anemone Ostiactis pearseae and intracellular bacteria was discovered at $~ 3700 \mathrm{~m}$ deep hydrothermal vents in the southern Pescadero Basin, Gulf of California. Unlike most sea anemones observed from chemically reduced habitats, this species was observed in and amongst vigorously venting fluids, side-by-side with the chemosynthetic tubeworm Oasisia aff. alvinae. Individuals of $O$. pearseae displayed carbon, nitrogen, and sulfur tissue isotope values suggestive of a nutritional strategy distinct from the suspension feeding or prey capture conventionally employed by sea anemones. Molecular and microscopic evidence confirmed the presence of intracellular SUP05-related bacteria housed in the tentacle epidermis of 0 . pearseae specimens collected from 5 hydrothermally active structures within two vent fields $\sim 2 \mathrm{~km}$ apart. SUP05 bacteria (Thioglobaceae) dominated the O. pearseae bacterial community, but were not recovered from other nearby anemones, and were generally rare in the surrounding water. Further, the specific Ostiactisassociated SUP05 phylotypes were not detected in the environment, indicating a specific association. Two unusual candidate bacterial phyla (the OD1 and BD1-5 groups) appear to associate exclusively with 0 . pearseae and may play a role in symbiont sulfur cycling.
\end{abstract}

Conclusion: The Cnidarian Ostiactis pearseae maintains a physical and nutritional alliance with chemosynthetic bacteria. The mixotrophic nature of this symbiosis is consistent with what is known about other cnidarians and the SUP05 bacterial group, in that they both form dynamic relationships to succeed in nature. The advantages gained by appropriating metabolic and structural resources from each other presumably contribute to their striking abundance in the Pescadero Basin, at the deepest known hydrothermal vents in the Pacific Ocean.

Keywords: Actiniaria, Chemoautotrophic, SUP05, Gulf of California, Pescadero Basin, Sulfide-oxidizing, Symbiosis, Chemosynthetic, Ostiactis

\footnotetext{
* Correspondence: sgoffredi@oxy.edu

'Occidental College, Los Angeles, LA, USA

Full list of author information is available at the end of the article
}

\section{$\triangle B M C$}

(c) The Author(s). 2020, corrected publication 2021. Open Access This article is licensed under a Creative Commons Attribution 4.0 International License, which permits use, sharing, adaptation, distribution and reproduction in any medium or format, as long as you give appropriate credit to the original author(s) and the source, provide a link to the Creative Commons licence, and indicate if changes were made. The images or other third party material in this article are included in the article's Creative Commons licence, unless indicated otherwise in a credit line to the material. If material is not included in the article's Creative Commons licence and your intended use is not permitted by statutory regulation or exceeds the permitted use, you will need to obtain permission directly from the copyright holder. To view a copy of this licence, visit http://creativecommons.org/ licenses/by/4.0/. The Creative Commons Public Domain Dedication waiver (http://creativecommons.org/publicdomain/zero/1. 0/) applies to the data made available in this article, unless otherwise stated in a credit line to the data. 


\section{Background}

Numerous deep-sea annelids, mollusks, and other invertebrates have forged relationships with bacteria in order to harness inorganic sources of energy that are typically unavailable to most animals. Microbial chemosynthesis generates energy through the oxidation of sulfide, as an example, used to fuel the production of organic carbon, which can be shared with a receptive animal host. To date, members of at least six major animal clades, including most recently Trichoplax (Placozoa), have formed symbiotic associations with internal chemosynthetic bacteria [1, 2]. Interestingly, Cnidaria, although well-known to host photosynthetic symbionts, remains one of the last prominent animal clades without a documented metabolic dependence on chemosynthetic bacterial symbionts for survival in hydrothermal vents.

Anthozoa, which includes sea anemones and corals, is one of the most successful and diverse groups of Cnidaria. They are found in all marine habitats at most depths and latitudes [3]. Their worldwide ecological success may best be attributed to an ability to form symbiotic relationships with other organisms, including microbial eukaryotes (e.g., dinoflagellates in the family Symbiodiniaceae; [4]), as in the case of shallow-water tropical species. Anthozoa such as sea anemones, octocorals, and zoanthids are also found in deep-sea reducing environments, such as hydrothermal vents, seeps, and whalefalls [5-8]; however, they have been historically understudied, and most remain undescribed. It would be reasonable, and perhaps even expected, for some of these deep-sea Anthozoa to also host microbial symbionts. In fact, a recent study demonstrated an affiliation between sulfide-oxidizing SUP05 bacteria and certain species of Anthozoa found near deep-sea seeps, and hypothesized a facultative symbiosis based on molecular and isotopic evidence [9].

The recently discovered Pescadero Basin vent field at $3700 \mathrm{~m}$ depth in the southern Gulf of California differs markedly from nearby vent localities (e.g., Guaymas Basin and $21^{\circ} \mathrm{N}$ East Pacific Rise) in physical, chemical, and biological attributes [10-12]. In particular, the vents in the Pescadero Basin are uniquely composed of hydrothermal calcite, with venting fluids that contain high levels of aromatic hydrocarbons, hydrogen, methane, and hydrogen sulfide at a $\mathrm{pH}$ of $\sim 6.5$ [11]. The Pescadero Basin vents are also highly unusual in faunal composition with many new species and numerous others that do not occupy nearby regional vents (e.g., Alarcon Rise vents; $[11,13,14])$. Included in this group of unusual fauna was a very abundant white sea anemone (up to 68 individuals $\mathrm{m}^{-2}$ in some areas) that occurred in and amongst the siboglinid tubeworm Oasisia aff. alvinae, often very near to actively venting fluids (Fig. 1, [11]).
Previously, several unidentified Pescadero Basin Actiniaria (sea anemones) were reported to be quite depleted in tissue $\delta^{13} \mathrm{C}$ values (- 33 to $-38 \%$ [ $\left.[11,15]\right)$, compare to anemones that feed via traditional suspension feeding or prey capture. This evidence, along with their unusual life position and abundance in zones of active fluid venting, hinted at their possible nutritional reliance on chemoautotrophic carbon production, as opposed to traditional suspension feeding or prey capture via cnidae; however, the specific details were not explored further. Here, by combining microbial community profiling, ultrastructural analysis via microscopy, and stable isotope measurements, we document the only known species of chemosynthetic sea anemone at vents deep in the Gulf of California, identified as Ostiactis pearseae (previously known only from whalefalls [5]). This dense population of $O$. pearseae likely receives nutritional supplementation of carbon, nitrogen, and sulfur via intracellular bacteria within the SUP05 clade, housed in their epidermis, albeit direct evidence of nutrient transfer remains outstanding.

\section{Results}

Actiniaria of various morphotypes were observed to be one of only a handful of dominant animal species in both the Pescadero Basin Auka vent field [11, 12] and the newly discovered JaichMaa 'ja'ag vent field, both within $\sim 2 \mathrm{~km}$ of each other in the Gulf of California (Fig. 1). A conspicuous white actiniarian species represented a significant fraction of the animal community and was collected from 5 vent edifices in zones of active venting, in the immediate vicinity of the obligate vent tubeworm, Oasisia aff. alvinae (Fig. 1). Several other sea anemones (by morphotype) were observed and collected near these same sites, usually in areas of less active fluid flow (Table 1). The white actiniarian morphotype was identified as Ostiactis pearseae [5], based on anatomical, cnidae, and DNA sequencing of preserved polyps. The Pescadero Basin populations of $O$. pearseae showed slight differences in morphology and cnidae to the description of specimens from the type locality and, thus, an amendment to the species diagnosis is provided.

\section{Ostiactis pearseae species diagnosis - Amendment}

Class Anthozoa Ehrenberg, 1834

Subclass Hexacorallia Haeckel, 1896

Order Actiniaria Hertwig, 1882

Suborder Enthemonae Rodríguez et al. 2014

Superfamily Metridioidea Carlgren, 1893

Family Ostiactinidae Rodríguez et al. 2012

Genus Ostiactis Rodríguez et al. 2012

Ostiactis pearseae Daly \& Gusmão, 2007

(Figs. 2 and 3, Table 2; Additional file 1: Table S1) 

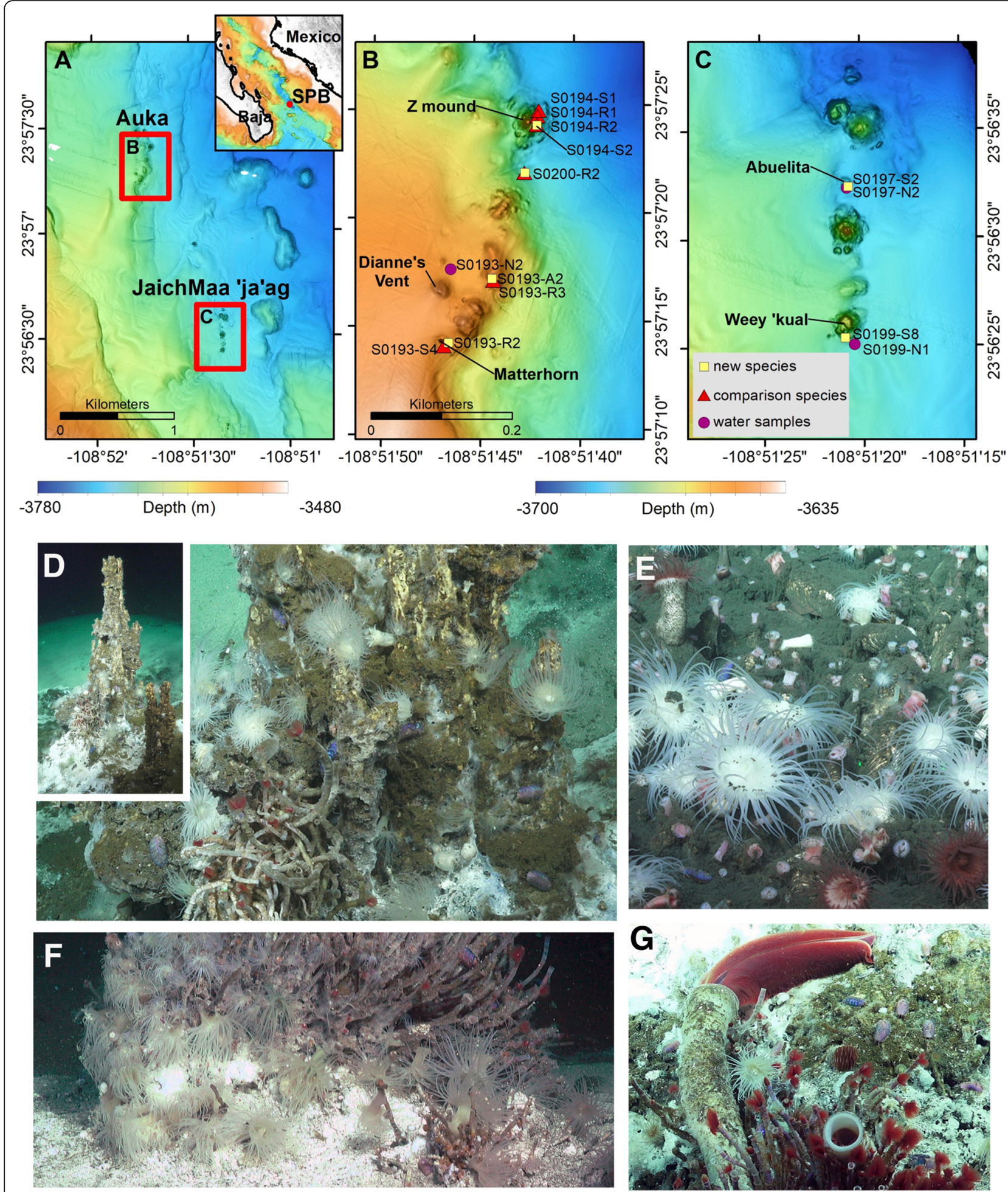

Fig. 1 Locations and in situ images of the actiniarian Ostiactis pearseae. a Location of South Pescadero Basin (SPB) vent fields Auka (in b) and JaichMaa 'ja'ag (in c). Inset shows the location of SPB at the mouth of the Gulf of California between the tip of the Baja Peninsula and mainland Mexico. b Auka vent field samples and chimneys (samples symbolized as in c). c JaichMaa 'ja'ag vent field samples and chimneys. Maps in $\mathbf{b}$ and $\mathbf{c}$ are at the same scale. All are in UTM Zone $12 \mathrm{~N}$. Legend shows the sample types. Maps $\mathbf{a}$, $\mathbf{b}$, and $\mathbf{c}$ show 1-m resolution bathymetry collected by mapping AUVs (owned and operated by the Monterey Bay Aquarium Research Institute). Color ramps show the depth ranges. $\mathbf{d}$-f Specimens of Ostiactis pearseae collected from both vent fields (shown as yellow squares in $\mathbf{b}$ and $\mathbf{c}$ ), indicated by arrows. $\mathbf{g}$ An individual 0 . pearseae near to the chemosynthetic tubeworms Riftia pachyptila and Oasisia aff. alvinae 
Table 1 Sample locations within the Pescadero Basin, Gulf of California, along with dive information, depth, and specimen descriptions for Anthozoa other than Ostiactis pearseae

\begin{tabular}{|c|c|c|c|c|}
\hline \multicolumn{5}{|l|}{ Ostiactis pearseae } \\
\hline Auka vent field & Dive \#-Sample \# & Depth (m) & Latitude $^{1}$ & Longitude $^{1}$ \\
\hline Matterhorn ${ }^{2}$ & S0193-R2 & -3655 & $23^{\circ} 57.24218^{\prime} \mathrm{N}$ & $108^{\circ} 51.77758^{\prime} \mathrm{W}$ \\
\hline E. of Diane's vent & S0193-A2 & -3655 & $23^{\circ} 57.28307^{\prime} \mathrm{N}$ & $108^{\circ} 51.73963^{\prime} \mathrm{W}$ \\
\hline$Z$ vent (top) ${ }^{2}$ & S0194-S2 & -3670 & $23^{\circ} 57.39937^{\prime} \mathrm{N}$ & $108^{\circ} 51.70276^{\prime} \mathrm{W}$ \\
\hline S. of Z vent (small chimney) & S0200-R2W & -3687 & $23^{\circ} 57.36546^{\prime} \mathrm{N}$ & $108^{\circ} 51.71477^{\prime} \mathrm{W}$ \\
\hline \multicolumn{5}{|l|}{ JaichMaa 'ja'ag vent field } \\
\hline Abuelita $^{2}$ & S0197-S2 & -3692 & $23^{\circ} 56.53971^{\prime} \mathrm{N}$ & $108^{\circ} 51.34850^{\prime} \mathrm{W}$ \\
\hline Weey 'kual & S0199-S8 & -3674 & $23^{\circ} 56.42347^{\prime} \mathrm{N}$ & $108^{\circ} 51.35257^{\prime} \mathrm{W}$ \\
\hline \multicolumn{5}{|l|}{ Water samples ${ }^{3}$} \\
\hline Auka vent field & Dive \#-Sample \# & Depth (m) & Latitude & Longitude \\
\hline E. of Diane's vent & S0193-N2 & -3642 & $23^{\circ} 57.29596^{\prime} \mathrm{N}$ & $108^{\circ} 51.77752^{\prime} \mathrm{W}$ \\
\hline \multicolumn{5}{|l|}{ JaichMaa 'ja'ag vent field } \\
\hline Abuelita & S0197-N2 & -3693 & $23^{\circ} 56.53998^{\prime} \mathrm{N}$ & $108^{\circ} 51.35074^{\prime} \mathrm{W}$ \\
\hline Weey 'kual & S0199-N1 & -3669 & $23^{\circ} 56.41838^{\prime} \mathrm{N}$ & $108^{\circ} 51.34473^{\prime} \mathrm{W}$ \\
\hline \multicolumn{5}{|l|}{ Other Anthozoa ${ }^{4}$} \\
\hline Auka vent field & Dive \#-Sample \# & Depth (m) & \multicolumn{2}{|l|}{ Description } \\
\hline Matterhorn & S0193-S4 & -3655 & \multicolumn{2}{|c|}{ Kadosactinidae 'sp.B' Green tentacles } \\
\hline E. of Diane's vent & S0193-R3 & -3655 & \multicolumn{2}{|c|}{ Unidentified zoanthid } \\
\hline Z vent (lower on structure) & S0194-R1 & -3670 & \multicolumn{2}{|c|}{ Unidentified zoanthid } \\
\hline NW. of Z vent (diffuse flow) & S0194-R2 & -3687 & \multicolumn{2}{|c|}{ Unidentified zoanthid } \\
\hline NW. of Z vent (diffuse flow) & S0194-S1 & -3687 & \multicolumn{2}{|c|}{ Unidentified zoanthid } \\
\hline S. of Z vent (small chimney) & S0200-R2r & -3692 & \multicolumn{2}{|c|}{ Kadosactinidae 'sp.B' Red tentacles } \\
\hline
\end{tabular}

${ }^{1}$ In degrees minutes. All are in UTM Zone $12 \mathrm{~N}$

${ }^{2}$ Anemones collected very near active Oasisia tubeworms

${ }^{3}$ Collected via Niskin sampler aboard the ROV SuBastian

${ }^{4}$ Collected in the same general venting structure as $O$. pearseae, geo-locations noted above

Diagnosis: (amended after [5, 7], modifications in italics). Ostiactinidae with basilar muscles and mesogleal marginal sphincter. Body with well-developed base. Column not clearly divisible into scapus and scapulus; scapus without cuticle, maybe with scattered demarcated suckers distally; column without cinclides or with a distal row of round papillae with inconspicuous cinclides. Tentacles regularly arranged, not thickened on the aboral side. Six pairs of perfect and fertile mesenteries, hexamerously arranged, not divisible into macro- and micro-cnemes. Same number of mesenteries proximally and distally. Retractor muscles weak but restricted. No acontia. Some populations with chemosynthetic bacteria in tentacles. Cnidom: Robust spirocysts, basitrichs, holotrichs, and p-mastigophores $A$ and B1. Ostiactis pearseae had been previously collected only in deep-sea waters (2800 m depth) of the Eastern Pacific, at a whalefall habitat in Monterey Bay [5]. Newly collected specimens are from deep-sea waters (3655-3692 m depth) associated with Southern Pescadero Basin hydrothermal vents (Diane's vent) in the Gulf of California (Pacific Ocean).
Intrapopulation variability in morphology was observed in the Pescadero Basin Ostiactis pearseae specimens (Fig. 2). Differences were observed mainly in the abundance and categories of cnidae amongst specimens (particularly holotrichs in the column), but also in the presence of a distal row of papillae (with only basitrichs) associated with inconspicuous cinclides in two specimens (SO197-S2 and SO200-R2; Fig. 2). Because of the small size of the papillae, the relatively small sizes and state of contraction and preservation condition of the specimens, it is not definitive that this row of distal papillae is only present in these two individuals. Nevertheless, the rest of the morphological and molecular characters, as well as the cnidae data, from the specimens with distal papillae agree with those of the other specimens studied, suggesting that differences should be treated as intrapopulation variation. Morphologically, specimens of $O$. pearseae from the Pescadero Basin possess $\sim 70$ tentacles, compared to specimens of similar sizes from the type locality, described as having $\sim 100$ tentacles [5], with some having poorly demarked suckers 

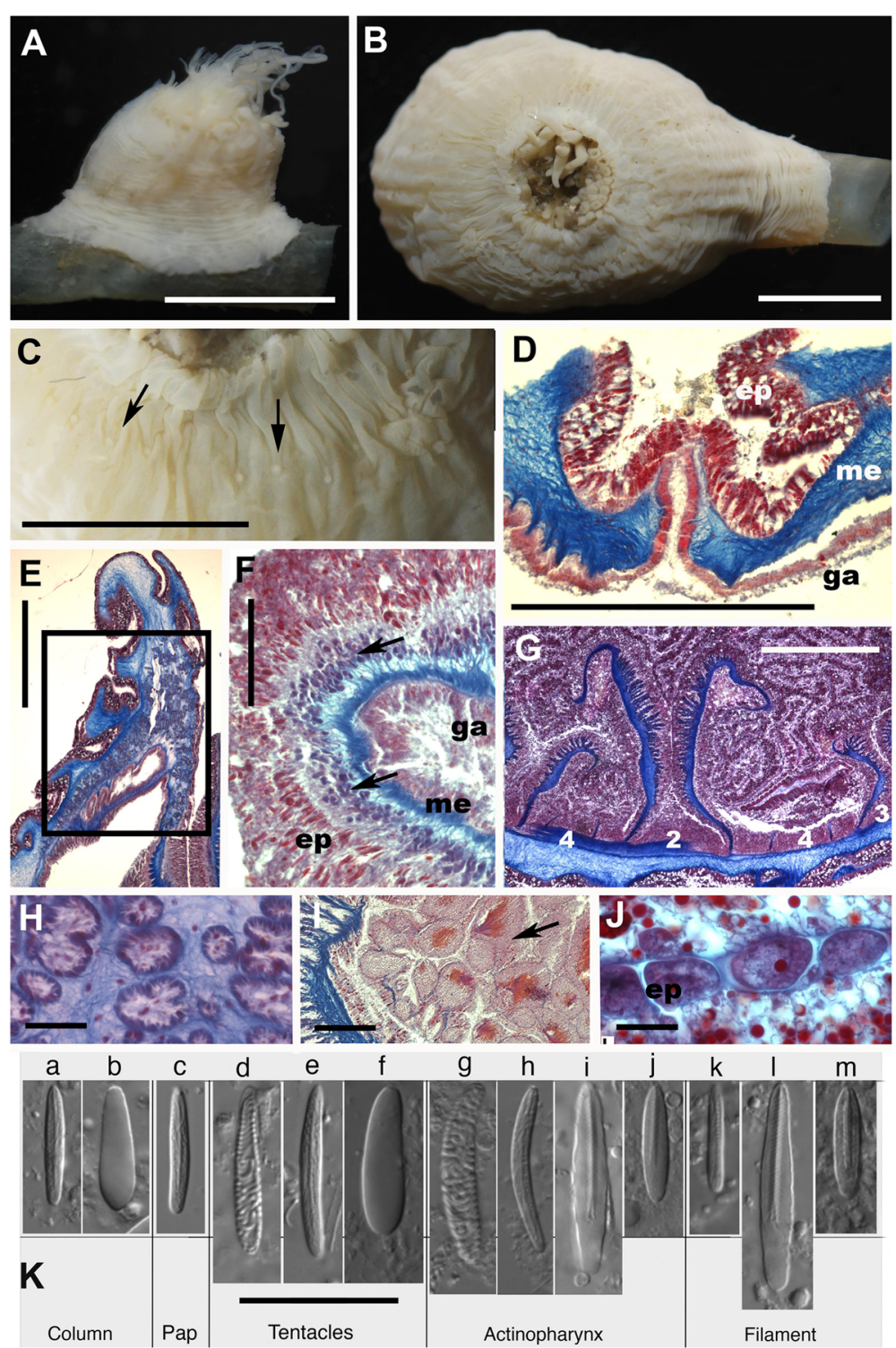

Fig. 2 Ostiactis pearseae external and internal anatomy, including cnidae. a, b External anatomy of Ostiactis pearseae from Pescadero Basin; a lateral view; b oral view. c Detail of the distal row of papillae in the column (arrows). d Detail of longitudinal section through perforated papillae (cinclide). e Longitudinal section of the distal column showing mesogleal marginal sphincter muscle (area within the rectangle). $\mathbf{f}$ Cross section of a tentacle showing ectodermal longitudinal muscles (arrows). $\mathbf{g}$ Cross section at the actinopharynx level showing cycles of mesenteries; numbers between mesenteries indicate different cycles. $\mathbf{h}$ Detail of marginal sphincter muscle fibers in the mesoglea. $\mathbf{j}$ Detail of developing oocytes and lipid inclusions (red small dots) in the gastrovascular cavity. $\mathbf{i}$ Detail of spermatic cysts (arrow points to largest cyst). $\mathbf{k}$ Cnidae types of O. pearseae: basitrichs ( $a, c, e, h, k)$, holotrichs (b, f), robust spirocysts (d, g), p-mastigophores A (i, l), p-mastigophores B1 (j, m). Abbreviations: ep, epidermis; ga, gastrodermis; me, mesoglea; pap, papillae. Scale bars: $\mathbf{a}-\mathbf{c}, 6 \mathrm{~mm} ; \mathbf{d}, \mathbf{g}, 1 \mathrm{~mm} ; \mathbf{e}, 0.5 \mathrm{~mm} ; \mathbf{f}, \mathbf{h}, \mathbf{i}, \mathbf{j}, 0.1 \mathrm{~mm} ; \mathbf{k}, 25 \mu \mathrm{m}$

in the column (which were not observed in Pescadero Basin specimens). Additionally, the first and second cycles of mesenteries are fertile in the type specimens, with males observed brooding larvae internally in the tentacles [5]. Although the fertility of the first cycle could not be confirmed for the Pescadero Basin specimens, the second and third cycles were confirmed to be fertile, but no brooding individuals were identified. The previous implementation of a different cnidae terminology suggests conspicuous differences in cnidae types and sizes between specimens at the Monterey Canyon whalefall and Pescadero Basin (Table 2), but a new more precise combined terminology used here allows for distinction within $p$-mastigophore capsules (i.e., $p$-mastigophores $\mathrm{A}$ and $p$-mastigophores B1). The types and size ranges of the original description and the newly collected specimens of $O$. pearseae mostly agree (with only slight variability in some size 


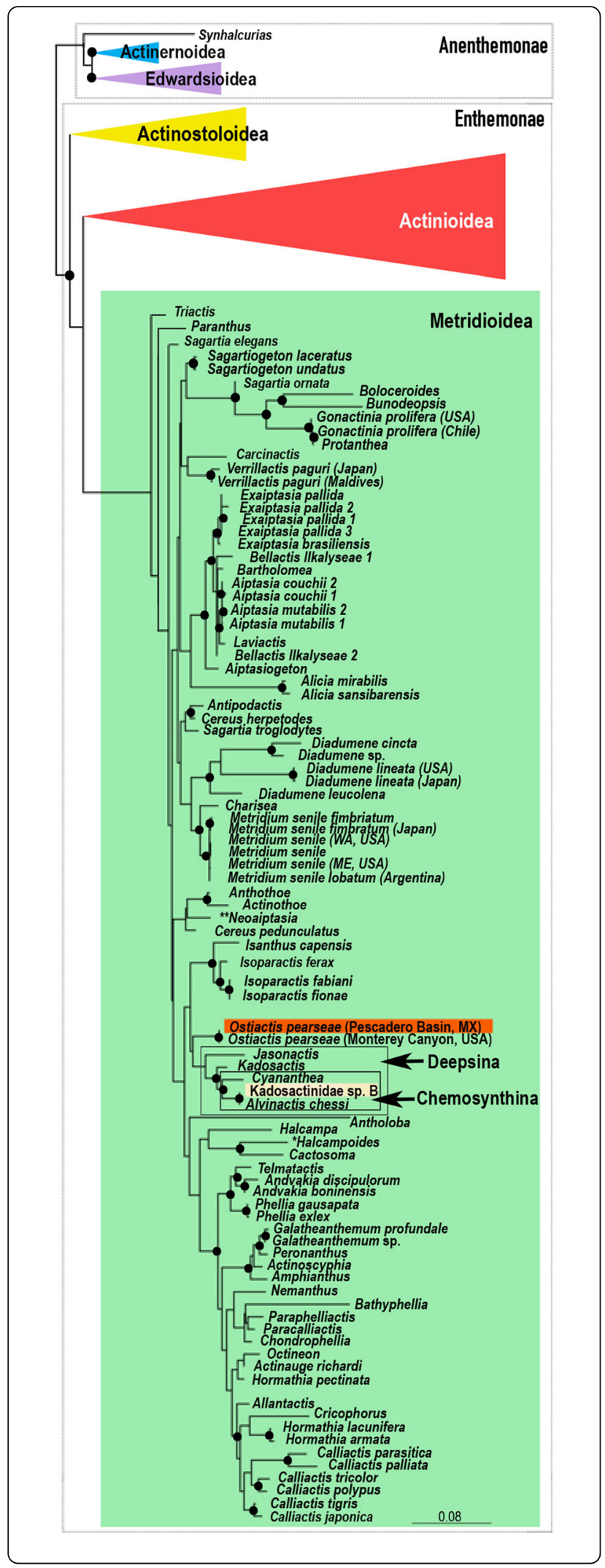

Fig. 3 Phylogenetic placement of Ostiactis pearseae. Phylogenetic reconstruction resulting from maximum likelihood analysis using PhyML (RaxML results not shown, but congruent) of the concatenated dataset of three mitochondrial (12S rDNA, $16 \mathrm{~S}$ rDNA, COIII) and two partial nuclear markers (18S and $28 \mathrm{~S}$ rDNA). Dotted boxes indicate actiniarian suborders; colored triangles and green box indicate actiniarian superfamilies; empty boxes and arrows indicate relevant actiniarian clades. Position of Ostiactis pearseae specimens from Pescadero Basin vent communities is highlighted in the orange box; the position of an additional sea anemone (unidentified morphospecies Kadosactinidae 'sp. B') is indicated by the light orange box. Bootstrap resampling values are indicated by black circles; only support values $>80 \%$ are shown

ranges), with the only distinct difference being the presence of $p$-mastigophores $\mathrm{B} 1$ capsules in the tentacles of the whalefall specimens, and not the Pescadero Basin specimens (Table 2).

All molecular phylogenetic analyses, based on the concatenated mitochondrial 12S rDNA, 16S rDNA, COIII genes, and partial nuclear $18 \mathrm{~S}$ rDNA gene, were congruent and revealed a well-supported clade comprised of specimens of Ostiactis pearseae from Pescadero Basin and the type locality of Monterey Canyon (Fig. 3). DNA sequences from the Pescadero Basin specimens were identical to the Monterey Canyon population for 3 of the genes analyzed and only differed from the type locality by 1-bp for the 16S rDNA gene. Ostiactis was recovered within Metridioidea, as sister to a weakly supported clade formed by deep-sea Actiniaria and those associated with chemosynthetic environments (e.g., clades Deepsina + Chemosynthina, as part of the family Kadosactinidae, sensu [7]), a relationship consistent over different studies (e.g., [7, 16-18]). Most representatives from these two clades are characterized by the loss of acontia (filament-like structures packed with nematocysts), the presence of which is a major synapomorphy for Metridioidea. The other actiniarian morphotype included here, identified as Kadosactinidae 'sp.B,' was recovered (only mitochondrial sequence data available for this specimen) sister to Alvinactis chessi, a sea anemone inhabiting hydrothermal vents in the southwestern $\mathrm{Pa}$ cific (Fig. 3; [6]).

\section{Isotope signatures of Ostiactis pearseae from the Pescadero Basin}

Tissue stable $\delta^{13} \mathrm{C}, \delta^{15} \mathrm{~N}$, and $\delta^{34} \mathrm{~S}$ isotope values were significantly different for Ostiactis pearseae than other anthozoans at the Pescadero Basin vent fields (ex. zoanthids; Fig. 4a). For example, O. pearseae had $\delta^{13} \mathrm{C}$ tissue values of $-29.1 \pm 4.6 \%$ o $(-40.1$ to $-24.3 \%$, $n=9)$, while the others measured $-20.6 \pm 2.7 \%$ o ( -25.4 to $15.5 \%, n=10 ; \pm 1$ SD; ANOVA $p=0.0001$; Fig. 4a). Similarly, O. pearseae had much more negative $\delta^{15} \mathrm{~N}$ tissue values of $1.6 \pm 1.7 \%$ o ( -0.4 to $5.3 \%$ ), whereas the 
Table 2 Size ranges of the cnidae capsules of Ostiactis pearseae [5]. $N$ total number of capsules measured. $S$ ratio of number of specimens in which each cnidae was found/number of specimens examined. $F$ frequency, $+++=$ very common, $++=$ common, $+=$ rather common, ${ }^{*}=$ sporadic

\begin{tabular}{|c|c|c|c|c|c|c|}
\hline Body region-Cnidae category & Range length $\times$ width $(\mu \mathrm{m})$ & $A v g \pm S D$ & $N$ & $S$ & $\mathrm{~F}$ & Range length $\times$ width $(\mu \mathrm{m})^{3}$ \\
\hline \multicolumn{7}{|l|}{ Column $^{1}$} \\
\hline Basitrichs & $17.2-26.0 \times 2.6-4.4$ & $21.7 \pm 2.3 \times 3.4 \pm 0.3$ & 122 & $6 / 6$ & ++ & $13.1-22.5 \times 1.9-3.0$ \\
\hline Holotrichs & $16.9-24.7 \times 4.8-8.6$ & $21.5 \pm 2.0 \times 6.4 \pm 0.8$ & 67 & $4 / 6$ & $* /++$ & $16.6-27.0 \times 3.5-5.5$ \\
\hline p-mastigophores B1 & - & - & & $0 / 6$ & & $17.8-33.9 \times 2.6-5.3$ \\
\hline \multicolumn{7}{|l|}{ Tentacles } \\
\hline Robust spirocysts & $15.9-41.9 \times 4.2-8.8$ & $26.0 \pm 6.1 \times 5.7 \pm 1.0$ & 85 & $5 / 5$ & ++ & $16.3-35.5 \times 2.1-5.8$ \\
\hline Basitrichs & $15.2-33.2 \times 2.3-4.3$ & $23.3 \pm 4.0 \times 3.5 \pm 0.5$ & 113 & $5 / 5$ & +++ & $16.2-29.8 \times 2.2-4.6$ \\
\hline Holotrichs & $15.6-28.5 \times 4.0-9.3$ & $23.3 \pm 2.7 \times 7.1 \pm 1.0$ & 79 & $5 / 5$ & + & $23.1-34.4 \times 2.9-6.9$ \\
\hline \multicolumn{7}{|l|}{ Actinopharynx } \\
\hline Basitrichs 1 & $16.4-20.2 \times 2.6-3.2$ & $18.1 \pm 1.7 \times 2.9 \pm 0.2$ & 5 & $2 / 3$ & * & $16.8-26.3 \times 2.0-3.3$ \\
\hline Basitrichs 2 & $23.7-34.0 \times 3.3-4.6$ & $27.9 \pm 2.8 \times 4.0 \pm 0.4$ & 20 & $2 / 3$ & ++ & $25.6-44.5 \times 3.0-4.3$ \\
\hline$p$-mastigophores $A^{2}$ & $23.3-38.1 \times 4.7-6.9$ & $30.7 \pm 3.5 \times 5.7 \pm 0.5$ & 53 & $3 / 3$ & ++ & - \\
\hline p-mastigophores $\mathrm{B} 1^{2}$ & $14.5-19.5 \times 4.0-5.2$ & $17.8 \pm 1.7 \times 4.5 \pm 0.4$ & 13 & $3 / 3$ & ++ & $22.0-37.0 \times 3.9-6.2$ \\
\hline \multicolumn{7}{|l|}{ Filaments } \\
\hline Basitrichs & $15.3-23.3 \times 2.5-3.5$ & $18.5 \pm 1.6 \times 3.0 \pm 0.2$ & 50 & $4 / 4$ & $* /+$ & $14.1-22.5 \times 1.8-2.9$ \\
\hline p-mastigophores $\mathrm{A}^{2}$ & $26.5-37.8 \times 4.8-6.7$ & $32.8 \pm 2.2 \times 5.7 \pm 0.5$ & 49 & $4 / 4$ & + & \\
\hline p-mastigophores $\mathrm{B} 1^{2}$ & $13.4-21.3 \times 3.6-6.3$ & $17.4 \pm 1.7 \times 4.6 \pm 0.6$ & 59 & $4 / 4$ & +++ & $17.5-37.6 \times 3.4-6.0$ \\
\hline
\end{tabular}

${ }^{1}$ Two specimens with papillae in distal column (see Fig. 2); papillae with only basitrichs of similar sizes than those in the rest of the column (i.e., $17.0-21.6 \times 2.7-3.7 \mu \mathrm{m}$ )

${ }^{2}$ Categories pooled together as microbasic p-mastigophores in Daly and Gusmão [5]

${ }^{3}$ Data from Daly and Gusmão [5]

others measured $10.6 \pm 6.3 \%$ o $(0.5-17.9 \%, n=10 ; \pm 1$ SD; ANOVA $p=0.0006$; Fig. 4a). These include lower $\delta^{15} \mathrm{~N}$ values observed for individuals of the Kadosactinidae 'sp.B' ( 0.5-2.8\%; Fig. 4a) collected at the same locality. By comparison, $O$. pearseae was significantly more negative in both tissue $\delta^{13} \mathrm{C}$ and $\delta^{15} \mathrm{~N}$ than the seep-associated octocoral species Paramuricea sp. type B3 recently reported [9] (ANOVA $p=0.0013$ and $p<$ 0.00001 , respectively, $n=21$; Fig. 4a). Finally, O. pearseae had significantly lower $\delta^{34} \mathrm{~S}$ tissue values of $-1.1 \pm 6.4 \%$ o ( -11.0 to $8.7 \%, n=7$ ), compared to other Pescadero Basin sea anemones $(8.9 \pm 5.2 \%$; range 1.0 to $14.2 \%$, $n=7$; ANOVA $p=0.008$ ), with comparable total tissue sulfur $\sim 0.9-1.9 \%$ by weight (Fig. $4 \mathrm{~b}$ ).

\section{Bacterial community analysis of Ostiactis pearseae from the Pescadero Basin}

In Ostiactis pearseae, the tentacles are smooth, tapering, and relatively long when extended, with features similar to most other anemones, including cnidocytes (or cnidoblasts), cnidocysts, and glandular cells, all common cellular components of sea anemone tentacles [21]. The presence of bacteria in the type specimens of $O$. pearseae from Monterey Canyon was not detected [5]; however, the unusual isotope signatures of the Pescadero Basin specimens $[11,15]$ prompted a more careful examination of this possibility. Indeed, bacterial community analysis via $16 \mathrm{~S}$ rRNA Illumina barcoding revealed a dominance of the gammaproteobacteria SUP05 clade (64-96\% of the bacterial community), comprising 6 putative sulfide-oxidizing bacterial OTUs (= phylotypes, clustered at $99 \%$ similarity) associated with the tentacles of Pescadero Basin O. pearseae ( $n=8$ specimens; Fig. 5, Additional file 2: Table S2). This was in contrast to the sulfide-oxidizing gammaprotebacteria recovered from the nearby obligate vent tubeworms Riftia pachyptila and Oasisia aff. alvinae (100\% identical to Candidatus Endoriftia persephone; Fig. 5a; [22]). The SUP05 clade was not detected in association with 6 other individual sea anemones (determined by morphotype or molecular sequencing), and the specific Ostiactis-associated SUP05 phylotypes were not detected in surrounding water samples $(n=3$; Fig. 5). Three SUP05 OTUs comprised $<7 \%$ of the bacterial community in the surrounding water column (Fig. 5a), based on the semi-quantitative $16 \mathrm{~S}$ rRNA barcoding, but were distinct, based on the 250-bp 16S rRNA Illumina barcode sequences (Additional file 3: Fig. $\mathrm{S} 1$ inset).

NMDS ordination revealed the total bacterial community of Ostiactis pearseae to be strongly differentiated from those associated with zoanthid specimens (analysis of similarity (ANOSIM) $R=0.99, p=0.002$ ), the other 

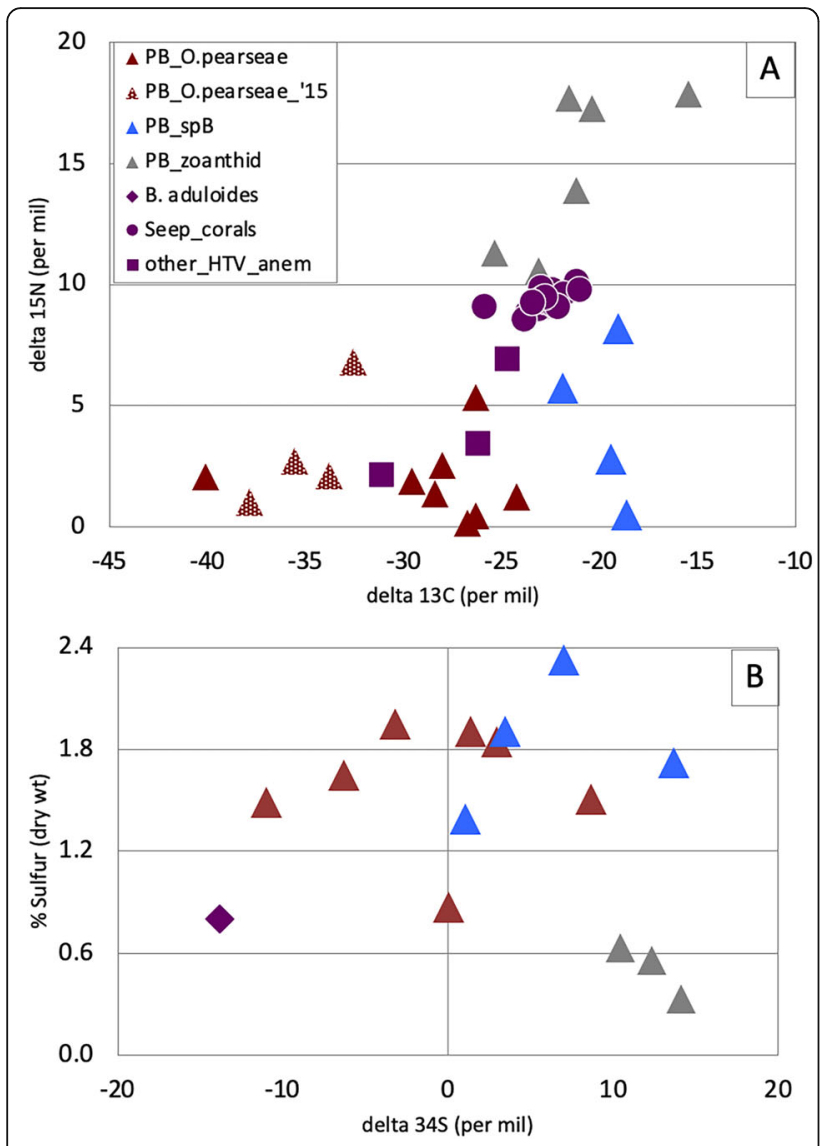

Fig. $4{ }^{13}$ Carbon, ${ }^{15}$ nitrogen, and ${ }^{34}$ sulfur isotope signatures for Ostiactis pearseae and comparison actiniarians. a $\delta^{13} \mathrm{C}$ and $\delta^{15} \mathrm{~N}$ values for the tentacles of Ostiactis pearseae from the Pescadero Basin vents, compared to neighboring anthozoans, including unidentified zoanthids ("zoan") and sea anemone (Kadosactinidae 'sp.B'). Data for Pescadero Basin actiniarians collected in 2015 (from [1 1]; red checkered triangles) as well as seep-associated corals from the Gulf of Mexico ([9]; purple circles) and unidentified anemones from Gorda Ridge hydrothermal vents ([19]; purple squares) are also included. Data from [9] was extracted from their Fig. 7 using an online Web plot digitizer (http://arohatgi.info/WebPlotDigitizer/). b $\delta^{34} \mathrm{~S}$ and tissue sulfide content (\%, dry weight) values for the tentacles of $O$. pearseae from the Pescadero Basin vents, compared to neighboring Anthozoa, including an unidentified zoanthid ("zoan") and sea anemone (Kadosactinidae 'sp.B'). Bathymodiolus aduloides from muddy sediments off of Kakaijima Island taken from [20]

unidentified sea anemone Kadosactinidae 'sp.B' (ANOSIM $R=0.87, p=0.022$ ), the water column samples (ANOSIM $R=1.00, p=0.006$ ), and the neighboring obligate vent tubeworms Riftia pachyptila and Oasisia aff. alvinae (ANOSIM $R=1.00, p=0.001$; Fig. $5 \mathrm{c}$ ). Bacterial community analysis revealed limited diversity within the tentacles of $O$. pearseae from the 5 different Pescadero Basin vent sites (Fig. 5a; Additional file 2: Table S2). Other bacteria uniquely recovered from $O$. pearseae tentacles included the BD1-5 group (a.k.a. Gracilibacteria; present in 5/8 O. pearseae specimens at 3-27\%) and the OD1 group (a.k.a. Parcubacteria; present in 5/8 O. pearseae specimens at 1-16\%; Fig. 5a). Additional bacterial groups present in non-Ostiactis sea anemones included Enterobacteriacea and Mollicutes (the latter 89\% similar to one recovered from an ascidian; Fig. 5a; EF137402; [23]). Microbial groups that were more common in all 3 water samples included the Methylococcales marine group 2 (MMG-2), Rhodobiacea, and Thaumarcheota (Fig. 5a).

To further characterize the SUP05 in association with Ostiactis pearseae, a longer region of the 16S rRNA gene was amplified via direct PCR and sequenced. A 1334-bp long 16S rRNA sequence, only 1-bp different from barcode OTU21762, was $96.5 \%$ similar to a free-living bacterium from a mud volcano in the Eastern Mediterranean Sea (AY592908; [24]) and 95\% similar to the thiotrophic symbiont of Bathymodiolus aff. brevior from Central Indian Ridge vents (DQ077891; [25]; Additional file 3: Fig. S1). There are no Bathymodiolus mussels at the Pescadero Basin vents, and the SUP05-related sequences recovered from $O$. pearseae are distinct from those recovered from Bathymodiolus from Costa Rica seeps, some of the closest known mussel populations (only $\sim 96 \%$ similar for 250-bp barcode sequence; Additional file 3: Fig. S1 inset; [26, 27]).

Several genes were additionally amplified and directly sequenced in order to inform the possible metabolic capabilities of the SUP05-related bacteria in $O$. pearseae. The napA gene, encoding a catalytic subunit of the periplasmic nitrate reductase alpha subunit (E.C. 1.7.99.4; [28]), amplified from O. pearseae tentacles, was most closely related $(82-85 \%$ similarity based on amino acid translation; $77 \%$ based on nucleotides), to the napA gene from known SUP05 bacteria, including those from an estuary (ACX30474; [29]) and the endosymbiont from Bathymodiolus mussel gill tissues (SMN16186). The aprA gene, encoding the adenosine phosphosulfate (or APS) reductase alpha subunit (E.C.1.8.99.2), recovered from $O$. pearseae, was most closely related to the aprA gene from the bacterial symbiont of a nematode ( $96 \%$ similarity based on amino acid translation, ACF93728) and the endosymbiont of Bathymodiolus septemdierum ( $81 \%$ similarity based on nucleotide sequence, AP013042; [30]).

Abundant SUP05 bacteria were observed embedded within the tentacle epidermis of Ostiactis pearseae (Fig. 6). Fluorescent in situ signal amplification via hybridization chain reaction-FISH (HCR-FISH) was necessary to overcome the very highly autofluorescent cnidae produced by the epidermis (Fig. 6g). HCR-FISH and TEM microscopy revealed intracellular cocci-shaped cells $(\sim 0.5 \mu \mathrm{m}$ diameter $)$, positioned just above or 


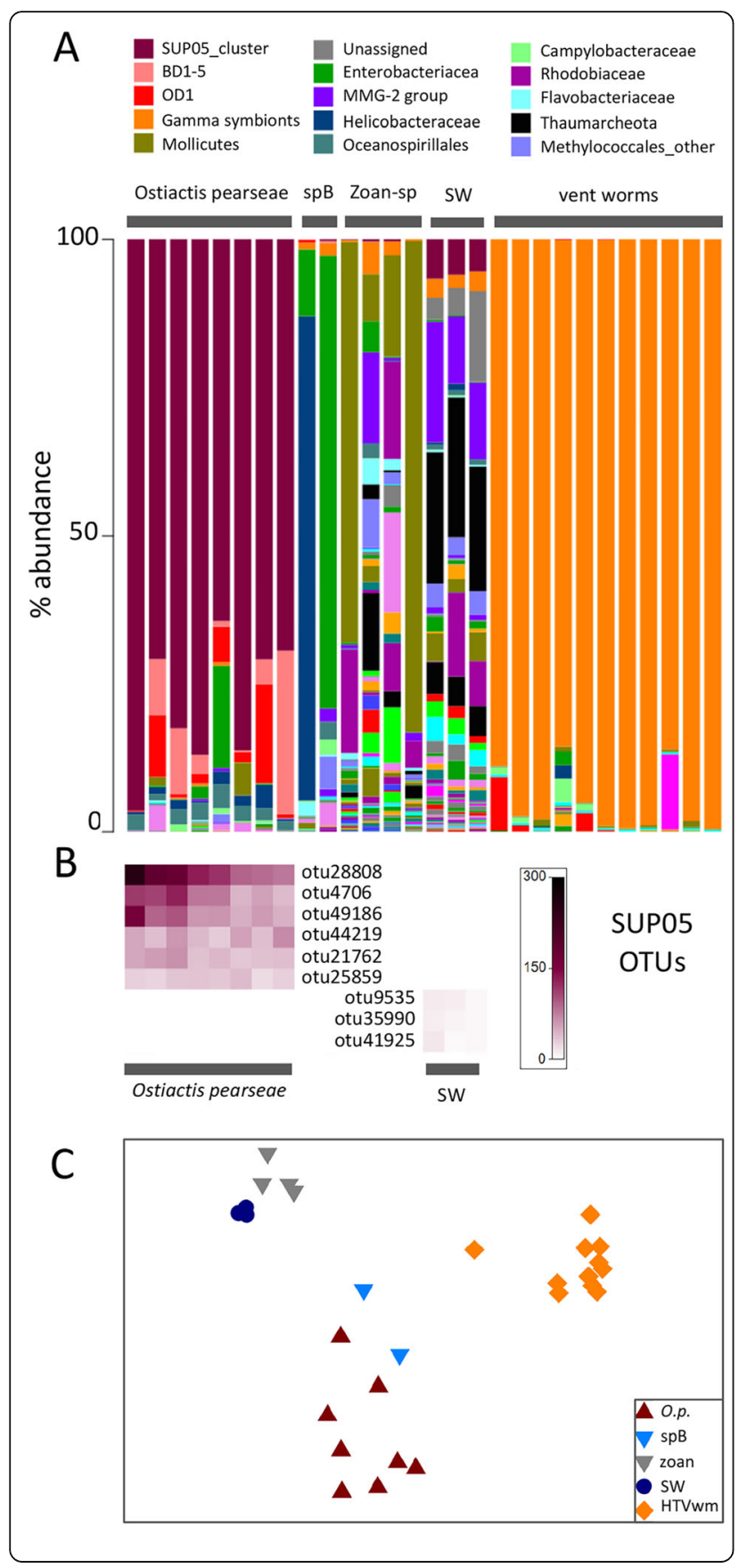

Fig. 5 Relative abundance of $16 \mathrm{~S}$ rRNA bacterial phylotypes, recovered from Ostiactis pearseae and comparison samples. a Relative abundance of bacterial families from Ostiactis pearseae from the Pescadero Basin vents, compared to neighboring Anthozoa, including unidentified zoanthids ("zoan") and Kadosactinidae "sp. B," nearby obligate vent tubeworms Riftia pachyptila and Oasisia aff. alvinae, and seawater. Each color on the graph represents a distinct family-level phylotype or lowest level available. The top 15 dominant family phylotypes are indicated in the key. $\mathbf{b}$ Six distinct SUP05 OTUS (99\% 16S rRNA sequence similarity) recovered from O. pearseae, compared to the surrounding seawater. The heatmap scale reflects the number of reads per sample. Phylogenetic relationships between the SUP05 OTUs are shown in Additional file 3: Fig. S1. c Non-metric multidimensional scaling (NMDS) ordination of microbial communities associated with $O$. pearseae, versus the other neighboring species and overlying seawater. Each point represents all $16 \mathrm{~S}$ rRNA sequences recovered from a single specimen or sample. ANOSIM $p<0.022$, suggesting a significant difference between $O$. pearseae and any other sample set (ex. other sea anemones, water samples; $R=0.88-1.00)$. HTV, hydrothermal vent; $\mathrm{spB}$, another undescribed sea anemone (Kadosactinidae 'sp.B') from the Pescadero Basin; zoan, unidentified zoanthids from the Pescadero Basin

immediately adjacent to cnidae capsules and nuclei (Fig. 6g, i, j). These cells were putatively identified as members of the SUP05 group, given the consistent overlap between cells hybridized using a general bacterial probe set (Eub338-I-III) and a probe designed specifically to target the $O$. pearseae SUP05 (Additional File 4: Fig. S2). Although poor tissue fixation somewhat compromised high-resolution electron microscopy (ex. many host cells were visibly ruptured with jumbled mitochondria), TEM provided additional evidence of symbiont integration within $O$. pearseae. Bacteria within the tentacles appeared concentrated in the periphery of cells within the mono-layered epidermis (Fig. 6i). Additionally, glands with large electron dense vesicles were observed occasionally between the very elongated bacteriacontaining cells (Fig. $6 \mathrm{~g}$ ) and a layer of mucous was observed overlying the epidermis in some instances. Bacteria on the tentacle surface occasionally appeared to be in clathrin-coated pits in various stages of endocytosis (Fig. 6l). For both microscopy methods, bacteria were not observed in either the gastrodermis or mesoglea of O. pearseae (Fig. 6g).

\section{Discussion}

A conspicuous actiniarian species, identified as Ostiactis pearseae [5], was dominant at two neighboring hydrothermal vent fields in the Pescadero Basin, Gulf of California. Unlike most vent anemones, which are almost always observed in the vent periphery, this species was found very near to vigorous venting fluids on and amongst the obligate vent tubeworms Oasisia aff. alvinae and Riftia pachyptila (Fig. 1), known to rely 

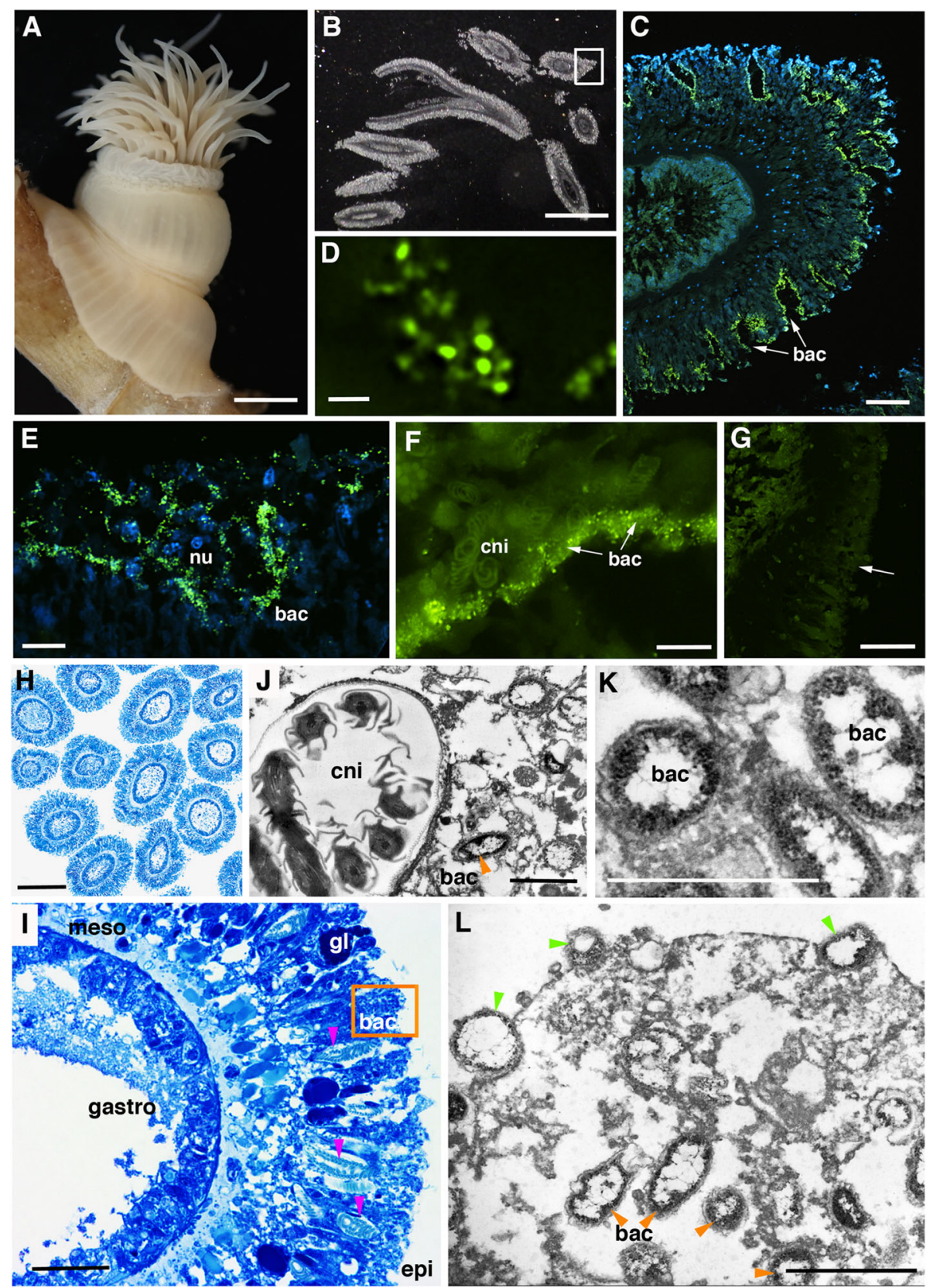

Fig. 6 Microscopy of the tentacles of Ostiactis pearseae. a Whole image of specimen SO194-S2, SIO-BIC Co3067. b Light microscopy of 3- $\mu$ m sections embedded in Steedman's resin. c-f Fluorescent in situ signal amplification via hybridization chain reaction-FISH (HCR-FISH) microscopy of Ostiactis pearseae tentacles. An unlabeled probe (Anem_SUP05), with a specific sequence initiator tag, was designed to be an exact match to the putative thiotrophic symbiont (related to the SUP05 clade). This probe was then amplified via HCR-FISH using DNA hairpins labeled with Alexa488, shown in green. DAPI-stained nuclei of host cells are shown in blue. $\mathbf{f}$ Bacteria can be seen within the epidermis (arrows), in and amongst nuclei, positioned just above or immediately adjacent to cnidocysts. $\mathbf{g}$ Fluorescent in situ signal amplification via HCR-FISH microscopy of Ostiactis pearseae tentacles without a probe. No bacteria are observed within the epidermis (arrow indicates the same region as in $\mathbf{f}$ ). Note: future microscopy using non-specific probes would help elucidate the extent of the symbiont layer. $\mathbf{h}, \mathbf{i}$ Light microscopy of $O$. pearseae tentacles. $\mathbf{j}-\mathbf{I}$ Transmission electron (TEM) microscopy of $O$. pearseae tentacles. $\mathbf{i}$ Bacteria are concentrated in the periphery of elongated epidermal cells (designated by the orange box, which corresponds to the area of TEM imagery), and positioned near cnidae, shown in pink arrowheads. No bacteria were observed in the mesogloea or gastrodermis. $\mathbf{j}$ Close-up of bacteria near a cnidocyst capsule, with an enclosed tubule. k Close-up showing clear membranes surrounding the bacterial cells, designated by orange arrowheads. I Arrowheads (in green) point to bacteria possibly being endocytized via clathrin-coated pits, as well as nearby clusters of bacterial cells within the elongated epidermal cells of 0 . pearseae. nu, nucleus; bac, bacteria; cni, cnidae; meso, mesoglea; gastro, gastrodermis; epi, epidermis. Scale bars are $5 \mathrm{~mm}(\mathbf{a}), 2 \mathrm{~mm}$ (b), 50 $\mu \mathrm{m}(\mathbf{c})$, $1 \mu \mathrm{m}(\mathbf{d}), 10 \mu \mathrm{m}(\mathbf{e}-\mathbf{g}), 250 \mu \mathrm{m}(\mathbf{h}), 25 \mu \mathrm{m}(\mathbf{i})$, and $1 \mu \mathrm{m}(\mathbf{j}-\mathbf{l})$ 
exclusively on sulfide-based chemosynthesis for energy [31, 32]. Ostiactis pearseae, formerly named Anthosactis pearseae [7], had been originally described as the first and only endemic Actiniaria from a whalefall community [5]; however, this discovery at hydrothermal vents makes them one of the only sea anemones described from multiple chemosynthetic environments $[6,7]$. The assumption, until now, was that most sea anemones at hydrothermal vents and methane seeps acquire nutrients via suspension feeding. There was no previous evidence that Ostiactis pearseae harbored chemosynthetic bacteria [5], suggesting that they fed upon dissolved and particulate organic matter and plankton. However, the significantly negative $\delta^{13} \mathrm{C}$ and $\delta^{15} \mathrm{~N}$ tissue isotopic values of $O$. pearseae (at the time labeled as an unidentified species in $[11,15])$ suggested an entirely different strategy dependent upon bacteria chemosynthesis.

Indeed, distinct bacterial phylotypes related to the SUP05-group were associated with Ostiactis pearseae, compared to other nearby sea anemones and water column bacterial communities. This association was pervasive and dominant, in that SUP05 bacteria were found in all 8 O. pearseae specimens analyzed, comprising up to $96 \%$ of the recovered microbial $16 \mathrm{~S}$ rRNA genes. Sulfuroxidizing bacteria within the SUP05 clade, named after the discovery in the Suiyo seamount plume [33], have been found worldwide in marine oxygen-deficient marine environments, deep-sea hydrothermal systems, and productive upwelling regions [34-36]. They exist both as free-living cells [29] and in association with animal hosts (ex. Bathymodiolus mussels and some sponges [37]), where they participate centrally in the provisioning of fixed carbon to the animal.

Intracellular SUP05 were observed exclusively in the epidermis of Ostiactis pearseae, which was unexpected given that most Cnidaria house symbionts, mainly photosynthetic, in the gastrodermis [38, 39]. Epidermal bacteriocyte-like structures containing Vibrio have been observed in Exaiptasia pallida [40] and bacterial "aggregates" containing Endozoicimonas have been observed in epidermal "caverns" in the sea anemone Metridium senile [41]. In both cases, however, the epidermal bacteria are pathogens commonly associated with animals [42, 43]. Octocorals harbored a coral-specific SUP05 clade that dominated their bacterial communities by up to $87 \%$, albeit the specific location of the bacteria within the coral mucous or tissue was not determined [9]. Interestingly, bacteria on the tentacle surface of $O$. pearseae appeared to be in clathrin-coated pits in various stages of endocytosis. Further examination of this receptor-mediated process is necessary to establish whether bacteria are actively transported inside of host cells and if so, what influences the recognition and selectivity of this process.
Hosting sulfide-oxidizing SUP05 in the outer epidermis may allow Ostiactis pearseae to avoid sulfide toxicity or the costly evolution of unique biochemistry to take up and transport sulfide [11]. Additionally, the epidermis in Anthozoa can function in nutrition [21], even more so than the gastrodermis, through direct uptake of dissolved organic compounds $[44,45]$, thus the positioning of nutritional bacteria in the epidermis may increase effective exchange of small molecules. Like other SUP05 cells, those associated with the tentacles of $O$. pearseae were small $(\sim 500 \mathrm{~nm}$ in diameter [46]). Presumably, these symbionts require both oxygen and sulfide near simultaneously, for example "Candidatus Thioglobus autotrophicus," a member of the SUP05 group, has an aerobic phenotype and uses sulfide while respiring oxygen $[46,47]$. In this regard, it would be reasonable to house bacteria as close to the tissue surface as possible in order to accommodate gas exchange and meet symbiont metabolic demands.

The assumption that the SUP05 group may perform a nutritional role for the Pescadero Basin Ostiactis pearseae is evidenced by the comparatively light tissue $\delta^{13} \mathrm{C}$ values (average -29.1\%). The contribution of chemosynthesis-derived carbon to $O$. pearseae biomass appears to exceed that reported for other deep-sea anthozoan species from the Gulf of Mexico (ex. Paramuricea [9]). The facultative, or rather mixotrophic, nature of the SUP05-Anthozoa symbioses proposed by [9] is also suggested for $O$. pearseae given the large range in negative $\delta^{13} \mathrm{C}$ values observed. Additionally, the SUP05 were found to not only have the gene repertoire necessary for chemosynthesis, but to be transcriptionally active, further supporting the possibility of SUP05 contributions to host nutrition [9]. Like all sea anemones (even those with photosynthetic symbionts), O. pearseae retains an arsenal of nematocysts by which to capture prey; thus, this tentacular team-up with SUP05 symbionts likely provides only a portion of their diet, indicating a mixotrophic strategy.

The SUP05 clade is involved not only in mediating dark carbon fixation, but also in the cycling of nitrogen, whether by denitrification, as has been shown in freeliving SUP05 populations [29, 36] or assimilatory nitrate reduction, as in the case of symbiotic SUP05 $[9,48]$. A significant contribution to tissue nitrogen by microbial nitrate utilization may be possible for the SUP05 symbionts given the considerably low $\delta^{15} \mathrm{~N}$ values in $O$. pearseae (average 1.6\%) and the successful amplification of the SUP05-related periplasmic nitrate reductase alpha subunit (napA) gene. The actual abundance of SUP05 symbionts per individual anemone is not known, nor is the regulation of carbon or nitrogen nutrient exchange, and thus, the overall nutritional influence of the SUP05 bacteria is not yet quantifiable. 
Finally, Ostiactis pearseae tissue $\delta^{34} \mathrm{~S}$ values $(\sim-1 \%)$ represented a large offset from typical marine biomass (16-21\%o [49]), where biogenic sulfur is sourced from seawater sulfate with minimal isotopic fractionation (21\% [50]). The average $\delta^{34} \mathrm{~S}$ observed in O. pearseae tissues is consistent with typical hydrothermal vent fauna ( 5 to $+5 \%$ [51]), which are known to incorporate a local source of sulfur (e.g., volcanic, thermally altered sulfur at $\sim 0 \%$ o $[52,53])$ via internal symbioses or direct consumption of sulfide-oxidizing bacteria. However, several individuals of $O$. pearseae revealed even lower $\delta^{34} \mathrm{~S}$ values (down to $-11 \%$ ), which would likely require the additional incorporation of substantial sulfide produced via microbial sulfate reduction, which is expected to have a $\delta^{34} \mathrm{~S}$ signature of $-20 \%$ or lighter $[54,55]$. The incorporation of sulfide sourced from dissimilatory sulfate reduction, rather than hydrothermal sulfide, has been similarly proposed for SUP05-hosting Bathymodiolus mussels from both Kakaijima Island and the Kaikata Caldera, which had tissue $\delta^{34} \mathrm{~S}$ values of $-12 \%$ and $-25 \%$, respectively, with a comparable tissue sulfur content of $\sim 0.8 \%$ ( $n=$ only 1 specimen each $[56,57])$. The wide range of $\delta^{34} \mathrm{~S}$ values for $O$. pearseae tissues ( - 11 to $9 \%)$, compared to other thiosymbiont-hosting animal species, could be due to a combination of traditional feeding by the host, variable sulfide oxidation by the SUP05 symbionts (e.g., utilization of $\mathrm{H}_{2} \mathrm{~S}, \mathrm{HS}^{-}$, or other reduced $\mathrm{S}$ species, including endogenous elemental sulfur), or variation in the sulfur sourced from the petroleum-rich sediments of the Pescadero Basin.

Many uncultivated candidate bacterial phyla have been discovered in recent years within a variety of environments $[20,58,59]$. They usually have small genomes $(<$ $1 \mathrm{Mb}$ ) with dramatically reduced biosynthetic capabilities, and yet exist globally in both marine and terrestrial habitats [60]. Several of these candidate phyla, known as the OD1 and BD1-5 groups (also referred to as Parcubacteria and Gracilibacteria, respectively), comprised up to $16-27 \%$ of the Ostiactis pearseae bacterial community and are known to play an important role in sulfur cycling [60]. An ectosymbiotic or parasitic lifestyle for the OD1 has been proposed [61], given their inability to synthesize vitamins, amino acids, nucleotides, and fatty acids. Additionally, while most candidate phyla are found in anoxic habitats, some OD1 genomes contained genes suggestive of $\mathrm{O}_{2}$ use as a terminal electron acceptor [61, 62]. Although not previously associated with the sulfide-oxidizing SUP05 group, or any specific proteobacterial group, the role of OD1 in sulfur reduction [60] and their diverse repertoire for attachment and adhesion [61] forecasts a possible direct association with either the SUP05 bacteria or O. pearseae mucous, for example.

\section{Conclusion}

Despite 40+ years of appreciation for chemosynthetic symbioses and the continued search for their occurrence in the most well-known habitats, Cnidaria have only very recently been shown to associate with chemoautorophic bacteria. Here, we identify a hydrothermal vent sea anemone, Ostiactis pearseae, at $3700 \mathrm{~m}$ depth in the Pescadero Basin, Gulf of California, that appears to be nutritionally supported by internal chemoautotrophic bacteria. This species, one of only 2 dominant sessile animals observed on the vent chimneys, has an unusual life position, often located in and amongst vent-obligate siboglinid tubeworms, very near to actively venting fluids. Ostiactis pearseae houses putative sulfideoxidizing SUP05 bacteria (Thioglobaceae) in its epidermis, with which it appears to have established a mixotrophic nutritional strategy, based on a broad range of carbon, nitrogen, and sulfur isotopes. Facultative, or rather mixotrophic, nutritional symbioses are often more difficult to recognize, compared to obligate alliances, but they are surely more common in nature [63], particularly in Cnidaria which experience symbiont gain and loss readily and often retain an ability to capture prey $[9,64$, $65]$. So, too, is the difficulty in uncovering nested symbioses, often involving microbe-microbe synergies. In this study, an unusual abundance of two candidate phyla, Parcubacteria and Gracilibacteria (a.k.a. OD1 and BD15 , respectively) within $O$. pearseae tentacles, hints at the roles they may play in the cycling of nutrients within and on animal hosts. Cnidaria symbioses are considered foundational for coral reefs, and perhaps they also play an important role at hydrothermal vents. It would be worth investigating additional Anthozoa species observed to inhabit venting fluids at other sites worldwide [66-68], to see whether they have also forged nutritional relationships with chemosynthetic bacteria, such as the versatile SUP05 group.

\section{Methods}

\section{Specimen collections}

All specimens and water samples were collected from active vent sites within the Pescadero Basin, Gulf of California ( $3700 \mathrm{~m}$ depth), using the ROV SuBastian during the R/V Falkor expedition FK103118 (OctoberNovember 2018), specifically from six sites at two vent fields within $\sim 2 \mathrm{~km}$ of each other; the previously described Auka vent field [10-12] and a newly discovered JaichMaa 'ja' ag vent field (Fig. 1; Table 1). Sea anemones were collected by ROV manipulator or suction sampler (Additional File 5: Supplemental video) and preserved shipboard as described below in each analysis section. Targeted water samples (2 L) were collected, within $\sim 0.5 \mathrm{~m}$ from nearby anemones, via Niskin bottle mounted on the ROV SuBastian. 
Material examined for redescription of Ostiactis pearseae SIO-BIC Co3060 [GC18-0004] (S0193-R2): specimens: 2; details: fixative $4 \%$ paraformaldehyde; preservative $50 \%$ EtOH; Matterhorn, Auka Vent Field, Pescadero Basin, Mexico (23.95404 $\left.{ }^{\circ} \mathrm{N}, 108.86296^{\circ} \mathrm{W}\right) ; 3655 \mathrm{~m} ; 14 \mathrm{Nov}$ 2018. SIO-BIC Co3061 [GC18-0005] (S0193-A2): specimens: $1 ; 10 \%$ formalin, preserved 50\% $\mathrm{EtOH}$; Matterhorn to Diane's vent, Auka Vent Field, Pescadero Basin, Mexico $\left(23.95472^{\circ} \mathrm{N},-108.86233^{\circ} \mathrm{W}\right) ; 3655 \mathrm{~m}$; $14 \mathrm{Nov}$ 2018. SIO-BIC Co3067 [GC18-0028] (S0194-S2): specimens: 2; fixed: $10 \%$ formalin; $50 \% \mathrm{EtOH}$; Z Mound, Auka Vent Field, Pescadero Basin, Mexico $\left(23.95666^{\circ} \mathrm{N}\right.$, - $\left.108.86171^{\circ} \mathrm{W}\right) ; 3670 \mathrm{~m} ; 15$ Nov 2018. Material studied has been deposited in the Benthic Invertebrate Collection of Scripps Institution of Oceanography (University of California San Diego) and the Invertebrate Division collection of the American Museum of Natural History (AMNH) in New York.

Additional specimens examined in this study include Kadosactinidae 'sp.B' (SIO-BIC Co3065 [GC18-0012] (S0193-S4)) and the unidentified zoanthid (SIO-BIC Co3066 [GC18-0025] (S0194-S1)).

\section{Carbon, nitrogen, and sulfur isotope analysis}

Tissue samples were dissected at sea, rinsed in milli-Q water, and frozen at $-20^{\circ} \mathrm{C}$ until thawed, washed with milli-Q water, and dried for $48 \mathrm{~h}$ at $60^{\circ} \mathrm{C}$. Carbon and nitrogen isotope determinations of anemone tissues were made via isotope ratio mass spectrometry. Samples (0.2$0.8 \mathrm{mg}$ dry weight) were loaded in tin boats and analyzed for total organic carbon (TOC) and total nitrogen (TN) abundances and $\delta^{13} \mathrm{C}_{\text {org }}$ and $\delta^{15} \mathrm{~N}$ using a Flash 2000 Elemental Analyzer (Thermo Fisher Scientific) interfaced to a Delta V Plus IRMS (Thermo Fisher Scientific) at Washington University, MO, USA. Samples were interspersed with several replicates of both in-house standards and international reference materials, including IAEA-CH-6, IAEA-CH-3, IAEA-NO3, USGS-40, and USGS-41. TOC and TN abundances were quantified by integrating peak areas against those produced by inhouse standards across a range of masses. The isotopic values are expressed in permil (\%) relative to international standards V-PDB (Vienna Pee Dee Belemnite) and Air for carbon and nitrogen, respectively. The longterm standard deviation is $0.2 \%$ for $\delta^{13} C_{\text {org }}$ and $0.3 \%$ for $\delta^{15} \mathrm{~N}$. There was no significant difference in $\delta^{13} \mathrm{C}$ between a subset of samples processed with and without acid $(n=7$ each; ANOVA $p=0.974)$. Sulfur isotope analyses were performed by combusting $\sim 2-5 \mathrm{mg}$ (dry weight) of tissue using a Costech ECS 4010 elemental analyzer coupled to a Thermo Fisher Scientific Delta V Plus mass spectrometer. Sulfur isotope values are expressed in standard delta notation $\left(\delta^{34} S\right)$ in permil (\%) as a deviation from the Vienna Canyon Diablo
Troilite (VCDT) standard. The long-term standard deviation is $0.3 \%$ or $\delta^{34} \mathrm{~S}$ is $0.3 \%$ based on in-house and international standards, including NBS-127 and IAEA-S1.

\section{DNA extraction}

Specimens for molecular analysis (Table 1) were preserved immediately upon collection in 90\% ethanol and stored at $4{ }^{\circ} \mathrm{C}$. Total genomic DNA was extracted from tissues using the Qiagen DNeasy kit (Qiagen, Valencia, CA, USA) according to the manufacturer's instructions. Two-liter water samples were filtered onto a $0.22-\mu \mathrm{m}$ Sterivex-GP polyethersulfone filter (MilliporeSigma, St. Louis, MO, USA) and frozen at $-80^{\circ} \mathrm{C}$ until DNA analysis. DNA extraction from Sterivex PES filters was also performed using the Qiagen DNeasy kit, according to the manufacturer's instructions, with the exception of the first step where $2 \mathrm{ml}$ of ATL lysis buffer was added to the Sterivex filter, via Luer lock and syringe, and rotated at $56^{\circ} \mathrm{C}$ for $12 \mathrm{~h}$. This solution was recovered from the filter, also via Luer lock and syringe, and processed as usual.

\section{Molecular analysis of the microbial community}

A 1000-bp region of the gene coding for napA (periplasmic nitrate reductase) was amplified directly from Ostiactis tissues using the primers V16F (5'-GCNCCNTGYMGNTTYTGYGG-3') and V17R (5'-RTGYTGRTTRAANCCCATNGTCCA-3' [28]), while a 408-bp fragment of the aprA gene (subunit of particulate methane monooxygenase enzyme) was generated using primers, aps1F (5-TGGCAGATCATGATYMAYGG-3) and aps4R (5-GCGCCAACYGGRCCRTA-3, described in [69]). A 1465-bp fragment of the 16S rRNA gene was amplified using the primers $27 \mathrm{~F}$ and $1492 \mathrm{R}$. Annealing conditions of $50^{\circ} \mathrm{C}, 50^{\circ} \mathrm{C}$, and $54^{\circ} \mathrm{C}$ were used for napA, aprA, and 16SrRNA, respectively. Otherwise, all thermal protocols included the following steps: an initial $5 \mathrm{~min}$ denaturation at $94{ }^{\circ} \mathrm{C}$, then $1 \mathrm{~min}$ at $94{ }^{\circ} \mathrm{C}, 1 \mathrm{~min}$ annealing step, and $1 \mathrm{~min}$ at $72^{\circ} \mathrm{C}$, for 25 cycles, and a final $5 \mathrm{~min}$ extension at $72^{\circ} \mathrm{C}$. Amplification products were sequenced directly using Sanger sequencing, via Laragen Inc., and submitted to GenBank (accession numbers MW148238 and MW158470). Close environmental and cultured relatives were chosen using top hits based on BLAST (www.ncbi.nlm.nih.gov).

The V4-V5 region of the 16S rRNA gene was amplified using bacterial primers with Illumina (San Diego, CA, USA) adapters on the $5^{\prime}$ end 515F ( $5^{\prime}$-TCGTCGGCAGCGTCAG ATGTGTATAAGAGACAGGTGCCAGCMGCCGCG GTAA-3') and 806R (5'-GTCTCGTGGGCTCGGA GATGTGTATAAGAGACAGGGACTACHVGGGT WTCTAAT-3'; [70]). The PCR reaction mix was set up in duplicate for each sample with Q5 Hot Start High-Fidelity 
2x Master Mix (New England Biolabs, Ipswich, MA, USA) and annealing conditions of $54^{\circ} \mathrm{C}$ for 25 cycles. Duplicate PCR samples were then pooled, and $2.5 \mu \mathrm{L}$ of each product was barcoded with Illumina NexteraXT index 2 Primers that include unique 8-bp barcodes (P5 5'-AATGATACGGC GACCACCGAGATCTACAC-XXXXXXXX-TCGTCG GCAGCGTC-3' and P7 5' -CAAGCAGAAGACGGCA TACGAGAT-XXXXXXXX-GTCTCGTGGGCTCGG-3'). Secondary amplification with barcoded primers used conditions of $66^{\circ} \mathrm{C}$ annealing temperature and 10 cycles. Products were purified using Millipore-Sigma (St. Louis, MO, USA) MultiScreen Plate MSNU03010 with a vacuum manifold and quantified using Thermo Fisher Scientific (Waltham, MA, USA) QuantIT PicoGreen dsDNA Assay Kit P11496 on the BioRad CFX96 Touch Real-Time PCR Detection System. Barcoded samples were combined in equimolar amounts into a single tube and purified with Qiagen PCR Purification Kit 28104 before submission to Laragen (Culver City, CA, USA) for $2 \times 250$ bp paired end analysis on the Illumina MiSeq platform with PhiX addition of $15-20 \%$.

MiSeq 16S rRNA sequence data was processed in Quantitative Insights Into Microbial Ecology (v1.8.0). Raw sequence pairs were joined and quality-trimmed using the default parameters in QIIME. Sequences were clustered into de novo operational taxonomic units (OTUs) with 99\% similarity using UCLUST open reference clustering protocol, and then, the most abundant sequence was chosen as representative for each de novo OTU. Taxonomic identification for each representative sequence was assigned using the Silva-119 database, clustered at 99\% similarity. A threshold filter was used to remove any OTU that occurred below $0.01 \%$ in the combined samples dataset. Analyses are based on Bray-Curtis distances of fourthroot transformed data, which minimizes errors in the ordination due to PCR bias, while not sacrificing genuine differences between samples. Quantification and statistical analyses are described in the "Results" sections and figure legends. Comparisons were performed using ANOVA and statistical significance was declared at $p<0.05$. Statistical analyses of beta diversity (e.g., ANOSIM) were performed with Primer E. The raw Illumina 16S rRNA barcode sequences and metadata collected in this study are available from the NCBI Small Read Archive (BioProject \# PRJNA671766). The processed sequence data, as well as representative sequences, are available on the Dryad Digital Repository URL (https://doi.org/10.5061/dryad. mkkwh70wt, along with representative SUP05 OTUs in Additional File 6: DataFile S1).

Molecular analysis of the anemone host Ostiactis pearseae Phylogenetic relationships were determined via sequencing of three mitochondrial markers, the $12 \mathrm{~S}$ rRNA, $16 \mathrm{~S}$ rRNA, and cytochrome oxidase III genes, and the partial nuclear 18S rRNA gene. An 862-bp product of the $12 \mathrm{~S}$
rRNA gene was amplified via primers ANTMT12SF (5' AGCCACACTTTCACTGAAACAAGG-3') and ANTM T12SR (5'-GTTCCCYYWCYCTYACYATGTTACGAC3') according to [71]. A 473-bp product of the 16S rRNA gene was amplified via primers ANEM16SA (5' -CACT GACCGTGATAATGTAGCGT-3') and ANEM16SB (5' CCCCATGGTAGCTTTTATTCG-3') according to [72]. Finally, a 721-bp product of the cytochrome oxidase III (COIII) gene was amplified via primers COIIIF ( $5^{\prime}$-CATT TAGTTGATCCTAGGCCTTGACC-3') and COIIIR (5'-CAAACCACATCTACAAAATGCCAATATC-3') according to [72]. Finally, a 502-bp product of the $18 \mathrm{~S}$ rRNA gene was amplified via primers 18S-3F (5'-GTTCG ATTCCGGAGAGGGA-3') and 18S-5R (5' -CTTGGCAA ATGCTITCGC-3') according to [73]. Annealing conditions of $55^{\circ} \mathrm{C}, 51.5^{\circ} \mathrm{C}, 51{ }^{\circ} \mathrm{C}$, and $54{ }^{\circ} \mathrm{C}$ were used for 12SrRNA, 16SrRNA, COIII, and 18S rRNA, respectively. Otherwise, all thermal protocols included the following steps: an initial $5 \mathrm{~min}$ denaturation at $94{ }^{\circ} \mathrm{C}$, then $1 \mathrm{~min}$ at $94^{\circ} \mathrm{C}, 1 \mathrm{~min}$ annealing step, and $1 \mathrm{~min}$ at $72^{\circ} \mathrm{C}$, for 30 cycles, and a final $5 \mathrm{~min}$ extension at $72{ }^{\circ} \mathrm{C}$. Amplification products were sequenced directly using Sanger sequencing, via Laragen Inc., and are available via GenBank (accession numbers MW148236-MW148237, MW165066, MW172213-MW172214, and MW172220-MW172221).

Newly generated DNA sequences for Ostiactis pearseae (and those for morphotype identified as Kadosactinidae sp.B. in this contribution) were combined and analyzed with the dataset by [74] for each of the four markers (Additional File 1: Table S1). Sequences for each marker were separately aligned in MAFFT v.7 [75, 76], using the following settings: strategy, L-INS-I; scoring matrix for nucleotide sequences, 200PAM $/ \mathrm{k}=2$; gap open penalty, 1.53; offset value, 0.05. Alignments for each marker were analyzed separately and as a concatenated dataset (alignments available on the Dryad Digital Repository URL (https://doi.org/10.5061/dryad. mkkwh70wt)). For each gene region, the best model of nucleotide substitution was chosen using the Akaike information criterion (AIC) on jModeltest2 [77, 78] implemented on the CIPRES Portal [79]. Maximum likelihood (ML) analyses were performed using RAxML-NG v0.6.0 [80], using the appropriate model of nucleotide substitution for each gene partition (12S: $G T R+I+G ; 16 S$ : TVM+G; COIII: TPM3uf+I+G; 18S: TIM2+I+G; $28 \mathrm{~S}$ : GTR $+\mathrm{I}+\mathrm{G})$ in the combined alignment. The Majority Rule Criterion was used to assess clade support allowing bootstrapping to halt automatically (-autoMRE). All analyses were run with gaps treated as missing data.

\section{Morphology and cnidae analysis of the anemone host Ostiactis pearseae}

Specimens were examined whole and dissected. Histological sections $5-10 \mu \mathrm{m}$ thick were made from different 
body regions of two specimens using standard paraffin techniques and stained with Heidenhain Azan stain [81]. The distribution and size ranges of cnidae in the tissues were analyzed from six specimens using light DIC microscopy ( $\times 1000$ magnification, oil immersion). Twenty non-fired capsules of each cnida type (when possible) were photographed and measured at random. Cnidae size distribution offers information on the variability in capsule size for each type of nematocyst. We follow a nematocyst terminology that combines the classification of [82], modified by [83], thus differentiating "basitrichs" from " $b$-mastigophores" with that of $[84,85]$ which captures the underlying variation seen in "rhabdoids" (see [74] for more details). We include photographs of each type of nematocyst for reliable comparison across terminologies and taxa (see [86]). Higher-level classification for Actiniaria follows [16].

\section{Hybridization chain reaction-fluorescent in situ hybridization}

Specimens for fluorescence in situ hybridization (FISH) microscopy were initially preserved in $4 \%$ sucrosebuffered paraformaldehyde (PFA) and kept at $4{ }^{\circ} \mathrm{C}$ for 24-48 h. These PFA-preserved specimens were then rinsed with $2 \times \mathrm{PBS}$, transferred to $70 \%$ ethanol, and stored at $-20^{\circ} \mathrm{C}$. Tissues were dissected and embedded in Steedman's wax (1 part cetyl alcohol: 9 parts polyethylene glycol $(400)$ distearate, mixed at $\left.60^{\circ} \mathrm{C}\right)$. An ethanol to wax gradient of $3: 1,2: 1$, and $1: 1$, and $100 \%$ wax, was used to embed the samples $(1 \mathrm{~h}$ each treatment at $37^{\circ} \mathrm{C}$ ). Embedded samples were sectioned at $\sim 3-\mu \mathrm{m}$ thickness using a Leica RM2125 microtome and placed on Superfrost Plus slides.

The protocol and all solutions used for HCR-FISH were as specified by Molecular Technologies, Inc., and closely followed [87]. Sections were dewaxed in three $100 \%$ ethanol rinses, allowed to dry, and equilibrated in hybridization buffer (Molecular Technologies; 30\% formamide, $5 \times$ sodium chloride, sodium citrate $(\mathrm{SSC}=750$ $\mathrm{mM} \mathrm{NaCl}, 75 \mathrm{mM}$ sodium citrate), $9 \mathrm{mM}$ citric acid (pH 6.0), $0.1 \%$ Tween 20, $50 \mu \mathrm{g} / \mathrm{mL}$ heparin, $1 \times$ Denhardt's solution, $10 \%$ dextran sulfate), for $20 \mathrm{~min}$ at $37^{\circ} \mathrm{C}$. Excess buffer was removed and sections were hybridized overnight in a humidification chamber at $37^{\circ} \mathrm{C}$ in hybridization buffer, to which was added a final concentration of $5 \mathrm{nM}$ of an unlabeled DNA probe, designed to be an exact match to the Ostiactis pearseae SUP05 16S rRNA phylotype (Anem-SUP05, 5'-ACCATACTCT AGTTTGCCAG-3'), based on the probe, "BangT-642," specific for the thiotrophic SUP05 symbiont in Bathymodiolus mussels [88]. A general bacterial probe set (Eub338-I-III) was also used as a positive control. These probes contained a specific sequence initiator tag (termed B1 and B3) that triggered the oligomerization of pairs of fluorescently labeled DNA hairpins (i.e., the amplification step; [87]). The B1 initiator tag + linker (5' -GAGGAGGGCAGCAAACGGGAAGAGTCTTCC TTTACGATATT- $3^{\prime}$ ) was added to the $5^{\prime}$ end of the Anem-SUP05 probe. The B3 initiator tag + linker (5'-GTCCCTGCCTCTATATCTCCACTCAACTTTAAC CCGATATT-3') was added to the $5^{\prime}$ end of each of three Eub338 probes I-III and to the Anem-SUP05 probe. In this case, tag B1 was paired with Alexa647-labeled hairpins, and tag B3 was paired with Alexa488-labeled hairpins.

Excess probe was removed by sequentially washing the slides for $15 \mathrm{~min}$ at $37^{\circ} \mathrm{C}$ in probe wash buffer (Molecular Technologies; $30 \%$ formamide, $5 \times$ SSC, $9 \mathrm{mM}$ citric acid (pH 6.0), 0.1\% Tween 20,50 $\mu \mathrm{g} / \mathrm{mL}$ heparin) to which $5 \times$ SSCT $(750 \mathrm{mM} \mathrm{NaCl}, 75 \mathrm{mM}$ sodium citrate, $0.1 \%$ Tween $20, \mathrm{pH} 7$ ) had been added to final concentrations ( $\mathrm{vol} / \mathrm{vol}$ ) of $25 \%, 50 \%$, and then $75 \%$. This wash sequence was followed by two 15-min washes in $100 \% 5 \times$ SSCT at $37^{\circ} \mathrm{C}$. Before amplification, $6 \mathrm{pmol}$ of each hairpin, per reaction, was "snap-cooled" by heating to $95^{\circ} \mathrm{C}$ for $90 \mathrm{~s}$, followed by $25^{\circ} \mathrm{C}$ for $30 \mathrm{~min}$, in a thermocycler in separate PCR tubes. During this time, sections were equilibrated with amplification buffer (Molecular Technologies; $5 \times$ SSC, $0.1 \%$ Tween 20, 10\% dextran sulfate) at room temperature for $30 \mathrm{~min}$. For amplification, each "snapcooled" hairpin in a pair was added to $100 \mu \mathrm{l}$ amplification buffer (for a final hairpin concentration of $60 \mathrm{nM}$ for each amplifier hairpin), and then sections were incubated overnight $(\sim 18 \mathrm{~h})$ at room temperature on a rocking platform protected from light. To remove unbound hairpin sequences, sections were washed twice in $5 \times$ SSCT for 15 $\mathrm{min}$ at room temperature, followed by two 30 -min washes in $5 \times$ SSCT. Sections were rinsed with distilled water and counterstained with 4'6'-diamidino-2-phenylindole (DAPI, $5 \mathrm{mg} / \mathrm{mL}$ ) for $1 \mathrm{~min}$, rinsed again, and mounted in Citifluor. Tissues were examined by epifluorescence microscopy using either a Nikon E80i epifluorescence microscope with a Nikon DS-Qi1Mc high-sensitivity monochrome digital camera or a Zeiss Elyra microscope with an ANDOR-iXon EMCCD camera.

\section{Transmission electron microscopy}

Specimens for TEM and semi-thin sectioning were fixed in PFA and preserved in 50\% EtOH. Before embedding, specimens were rehydrated, post-fixed with $1 \% \mathrm{OsO}_{4}$, and subsequently dehydrated again in an ascending acetone series and embedded in Araldite. One-micrometer semi-thin sections were sectioned using a "Diatome Histo Jumbo" diamond knife on a Leica Ultracut $\mathrm{S}$ ultramicrotome and stained with toluidine blue ( $1 \%$ toluidine, $1 \%$ sodium-tetraborate, and $20 \%$ saccharose). Coverslips were mounted with Araldite and sections were imaged with an Olympus 
microscope (BX-51) equipped with the dot.slide system (2.2 Olympus, Hamburg). Silver interferencecolored sections $(70-75 \mathrm{~nm})$ were prepared using a "Diatome Ultra $45^{\circ}$ " diamond knife. The sections were placed on Formvar-covered, single-slot copper grids and stained with $2 \%$ uranyl acetate and lead citrate in an automated TEM stainer (QG-3100, Boeckeler Instruments). Ultra-thin sections were examined using a Zeiss EM10 transmission electron microscope with digital imaging plates (DITABIS Digital Biomedical Imaging Systems, Germany).

\section{Supplementary Information}

Supplementary information accompanies this paper at https://doi.org/10. 1186/s12915-020-00921-1.

Additional file 1: Table S1. Reference taxa included in this study, with voucher location and GenBank accession numbers. Taxa are organized alphabetically within their family; new sequences indicated in bold.

Additional file 2: Table S2. $16 S$ rRNA amplicon results. Number of total $16 S$ rRNA amplicon reads, the Shannon Diversity index $\left(\mathrm{H}^{\prime}\right)$ and the relative abundance (\%) of the SUP05 group (based on 16S rRNA barcode amplification) associated with Ostiactis pearseae, water samples, and other Anthozoa from the Pescadero Basin vents.

Additional file 3: Figure S1. Phylogenetic relationships of the SUP05 group, based on $16 \mathrm{~S}$ rRNA. A. SUP05 cluster, based on 165 rRNA. Taxa shown in green are known symbionts of marine invertebrates. ${ }^{*}>70 \%$ support (using the Jukes Kantor model). Additional taxa were included according to Petersen et al. 2012; Glaubitz et al. 2013; Shah et al. 2019. Inset. Shows SUP05 amplicons recovered from Ostiactis pearseae, surrounding seawater samples, and Bathymodiolus mussels from the Costa Rica margin Jaco Scar seep sites (SG, unpublished).

Additional file 4: Figure S2. Fluorescence Microscopy of the tentacles of Ostiactis pearseae. Fluorescent in situ signal amplification via hybridization chain reaction-FISH (HCR-FISH) microscopy of Ostiactis pearseae tentacles using A. a general bacterial probe set Eub338 I-III, B. the specific Anem_SUP05 probe, and $\mathbf{C}$. an overlay of the two showing near complete overlap. Scale is $10 \mu \mathrm{m}$.

Additional file 5 Sampling anemones. Sea anemones were collected by ROV manipulator or suction sampler mounted on ROV SuBastian. Also available from the Dryad Digital Repository (https://doi.org/10.5061/dryad. mkkwh70wt).

Additional file 6. $16 \mathrm{~S}$ rRNA amplicon sequence data. 16S rRNA Illumina barcode sequence data and QIIME processed data, including representative sequences for all OTUs, as well as representative sequences for the SUP05 OTUs specifically. Also available from the Dryad Digital Repository (https://doi.org/10.5061/dryad.mkkwh70wt).

\section{Acknowledgements}

We thank the captain and crew of the RN Falkor, ROV SuBastian pilots and technicians, as well as scientific participants of FK181031, chief scientists R. Zierenberg, D. Caress, and V. Orphan, as well as J. Paduan (MBARI) for Fig. 1 maps, R. Murali for assistance with HCR-FISH, and S. Connon for assistance with microbial community analysis.

We acknowledge, with gratitude, the granting of sample collection permits by la Dirección General de Ordenamiento Pesquero y Acuícola, Comisión Nacional de Acuacultura y Pesca (CONAPESCA: Permiso de Pesca de Fomento No. PPFE/DGOPA-200/18) and la Dirección General de Geografía y Medio Ambiente, Instituto Nacional de Estadística y Geografía (INEGI: Autorización EG0122018), with the associated Diplomatic Note number 182083 (CTC/07345/18) from la Secretaría de Relaciones Exteriores - Agencia Mexicana de Cooperación Internacional para el Desarrollo / Dirección General de Cooperación Técnica y Científica.

\section{Authors' contributions}

S.K.G. conducted the DNA analysis, including $16 \mathrm{~S}$ rRNA barcoding, host gene sequencing, and fluorescent microscope analyses; analyzed experimental data; wrote the manuscript with input from coauthors; and participated in the research expedition. C.M. conducted the DNA analysis, including 165 rRNA barcoding. E.T. performed electron microscopy analyses and participated in the research expedition. D.F. performed the isotope analyses and reviewed the paper. G.W.R. interpreted the electron microscopy analyses, advised on the species identification, and participated in the research expedition. L.G. conducted phylogenetic analysis and advised on host identification. E.R. conducted host anemone analyses for species identification, including morphology, and wrote the manuscript. All authors contributed to the data interpretation and editing of the paper. All authors read and approved the final manuscript.

\section{Funding}

Support for SKG and CM was provided by a Faculty Enrichment Grant and the Undergraduate Research Center, respectively, through Occidental College. Support for ET was provided, in part, by a post-doctoral fellowship from the German Research Foundation (DFG TI 973/1-1). The research expedition FK181031 was made possible via support from the Schmidt Ocean Institute.

\section{Availability of data and materials}

Amplification products were sequenced directly using Sanger sequencing, via Laragen Inc., and are available via the NCBI GenBank (accession numbers MW148236-MW148238, MW158740, MW165066, MW172213-MW172214, and MW172220-MW172221). Alignments for the anemone 12S rRNA, 16S rRNA, $18 \mathrm{~S}$ rRNA, and COIII for both Ostiactis pearseae and Kadosactinidae 'sp.B', used to generate Fig. 3, are also available on the Dryad Digital Repository URL listed below. Animal images and specimens were vouchered for longterm archiving into the Benthic Invertebrate Collection at Scripps Institution of Oceanography (sioapps.ucsd.edu/collections/bi/). The raw Illumina $16 \mathrm{~S}$ rRNA barcode sequences and metadata collected in this study are available from the NCBI Small Read Archive (BioProject \# PRJNA671766). The processed sequence data, as well as representative sequences, are available on the Dryad Digital Repository URL (https://doi.org/10.5061/dryad.mkkwh70wt).

Ethics approval and consent to participate

Not applicable

\section{Consent for publication}

Not applicable

\section{Competing interests}

The authors declare that they have no competing interests.

\section{Author details}

${ }^{1}$ Occidental College, Los Angeles, LA, USA. ${ }^{2}$ Washington University, St Louis, MO, USA. ${ }^{3}$ American Museum of Natural History, New York City, NY, USA. ${ }^{4}$ University of Bonn, Bonn, Germany. ${ }^{5}$ Scripps Institution of Oceanography, San Diego, CA, USA.

Received: 7 July 2020 Accepted: 7 November 2020

Published online: 18 January 2021

\section{References}

1. Dubilier N, Bergin C, Lott C. Symbiotic diversity in marine animals: the art of harnessing chemosynthesis. Nat Rev Microbiol. 2008;6(10):725-40.

2. Gruber-Vodicka HR, Leisch N, Kleiner M, Hinzke T, Liebeke M, McFall-Ngai M, Hadfield MG, Dubilier N. Two intracellular and cell type-specific bacterial symbionts in the placozoan Trichoplax H2. Nat Microbiol. 2019;4(9):1465-74.

3. Daly $M$, Chaudhuri $A$, Gusmão $L$, Rodríguez E. Phylogenetic relationships among sea anemones (Cnidaria: Anthozoa: Actiniaria). Molec Phylogen Evol. 2008;48(1):292-301.

4. LaJeunesse TC, Parkinson JE, Gabrielson PW, Jeong HJ, Reimer JD, Voolstra CR, Santos SR. Systematic revision of Symbiodiniaceae highlights the antiquity and diversity of coral endosymbionts. Curr Biol. 2018;28(16):2570-80.

5. Daly M, Gusmão L. The first sea anemone (Cnidaria: Anthozoa: Actiniaria) from a whale fall. J Nat Hist. 2007;41(1-4):1. 
6. Zelnio KA, Rodriguez E, Daly M. Hexacorals (Anthozoa: Actiniaria, Zoanthidea) from hydrothermal vents in the south-western Pacific. Mar Biol Res. 2009;5(6):547-71.

7. Rodríguez E, Barbeitos M, Daly M, Gusmão LC, Häussermann V. Toward a natural classification: phylogeny of acontiate sea anemones (Cnidaria, Anthozoa, Actiniaria). Cladistics. 2012;28(4):375-92.

8. Breedy O, Rouse GW, Stabbins A, Cortes J, Cordes EE. New records of Swiftia (Cnidaria, Anthozoa, Octocorallia) from off the Pacific Costa Rican margin, including a new species from methane seeps. Zootaxa. 2019;4671(3):407-19.

9. Vohsen SA, Gruber-Vodicka HR, Osman EO, Saxton MA, Joye SB, Dubilier N, Fisher CR, Baums IB. Deep-sea corals near cold seeps associate with chemoautotrophic bacteria that are related to the symbionts of cold seep and hydrothermal vent mussels. Microbiome. 2020;8:34.

10. Caress D, Troni G, Clague D, Paduan J, Martin J, Thomas H, Conlin D, Martin E, Meneses-Quiroz E, Nieves-Cardoso C, Santa Rosa del Rio M. Detection of active hydrothermal vent fields in the Pescadero Basin and on the Alarcón Rise using AUV multibeam and CTD data. 2015; Abstract OS23C-2027 presented at the AGU fall meeting, San Francisco, CA.

11. Goffredi SK, Johnson S, Tunnicliffe V, Caress D, Clague D, Escobar E, Lundsten L, Paduan JB, Rouse G, Salcedo DL, Soto LA. Hydrothermal vent fields discovered in the southern Gulf of California clarify role of habitat in augmenting regional diversity. Proc Royal Soc B. 2017;284(1859):20170817.

12. Paduan JB, Zierenberg RA, Clague DA, Spelz RM, Caress DW, Troni G, Thomas H, Glessner J, Lilley MD, Lorenson T, Lupton J. Discovery of hydrothermal vent fields on Alarcón Rise and in Southern Pescadero Basin, Gulf of California. Geochem Geophys Geosyst. 2018;19(12):4788-819.

13. Rouse GW, Wilson NG, Carvajal JI, Vrijenhoek RC. New deep-sea species of Xenoturbella and the position of Xenacoelomorpha. Nature. 2016;530(7588): 94-7

14. Hatch AS, Liew H, Hourdez S, Rouse GW. Hungry scale worms: Phylogenetics of Peinaleopolynoe (Polynoidae, Annelida), with four new species. ZooKeys. 2020;932:27

15. Salcedo DL, Soto LA, Paduan JB. Trophic structure of the macrofauna associated to deep-vents of the southern Gulf of California: Pescadero Basin and Pescadero Transform Fault. PLoS One. 2019;14(11):e0224698.

16. Rodríguez E, Barbeitos MS, Brugler MR, Crowley LM, Grajales A, Gusmão L Häussermann V, Reft A, Daly M. Hidden among sea anemones: the first comprehensive phylogenetic reconstruction of the order Actiniaria (Cnidaria, Anthozoa, Hexacorallia) reveals a novel group of hexacorals. PLoS One. 2014;9(5):e96998

17. Grajales A, Rodríguez E Elucidating diversity within the Aiptasiidae, a widespread cnidarian-dinoflagellate model system (Cnidaria: Anthozoa: Actiniaria: Metridioidea). Molec Phylogen Evol. 2016;94(A):252-263.

18. Gusmão LC, Rodríguez E, Daly M. Description of Calliactis tigris sp. nov: reconciling taxonomy and phylogeny in hermit-crab symbiotic anemones (Cnidaria: Actiniaria: Hormathiidae). Organisms Divers Evol. 2019;19(4):567-83.

19. Van Dover CL, Fry B. Microorganisms as food resources at deep-sea hydrothermal vents. Limnol Oceanogr. 1994;39(1):51-7.

20. Rinke C, Schwientek P, Sczyrba A, Ivanova NN, Anderson IJ, Cheng JF, Darling A, Malfatti S, Swan BK, Gies EA, Dodsworth JA. Insights into the phylogeny and coding potential of microbial dark matter. Nature. 2013; 499(7459):431-7.

21. Fautin DG, Mariscal RN. Cnidaria: Anthozoa. New York: Wiley-Liss; 1991

22. Robidart JC, Bench SR, Feldman RA, Novoradovsky A, Podell SB, Gaasterland T, Allen EE, Felbeck H. Metabolic versatility of the Riftia pachyptila endosymbiont revealed through metagenomics. Environ Microbiol. 2008; 10(3):727-37.

23. Tait E, Carman M, Sievert SM. Phylogenetic diversity of bacteria associated with ascidians in Eel Pond (Woods Hole, Massachusetts, USA). J Exp Mar Bio Ecol. 2007:342(1):138-46

24. Heijs SK, Sinninghe Damsté JS, Forney LJ. Characterization of a deep-sea microbial mat from an active cold seep at the Milano mud volcano in the Eastern Mediterranean Sea. FEMS Microbio Ecol. 2005;54(1):47-56.

25. McKiness ZP, Cavanaugh CM. The ubiquitous mussel: Bathymodiolus aff. brevior symbiosis at the Central Indian Ridge hydrothermal vents. Mar Ecol Prog Series. 2005:295:183-90.

26. Levin LA, Orphan VJ, Rouse GW, Rathburn AE, Ussler W III, Cook GS, Goffredi SK, Perez EM, Waren A, Grupe BM, Chadwick G. A hydrothermal seep on the Costa Rica margin: middle ground in a continuum of reducing ecosystems. Proc Royal Soc B. 2012:279(1738):2580-8.
27. McCowin MF, Feehery C, Rouse GW. Spanning the depths or depthrestricted: three new species of Bathymodiolus (Bivalvia, Mytilidae) and a new record for the hydrothermal vent Bathymodiolus thermophilus at methane seeps along the Costa Rica margin. Deep Sea Res Part I: Oceanogr Res Papers. 2020;164:103322.

28. Flanagan DA, Gregory LG, Carter JP, Karakas-Sen A, Richardson DJ, Spiro $S$. Detection of genes for periplasmic nitrate reductase in nitrate respiring bacteria and in community DNA. FEMS Microbiol Lett. 1999; 177(2):263-70.

29. Walsh DA, Zaikova E, Howes CG, Song YC, Wright JJ, Tringe SG, Tortell PD, Hallam SJ. Metagenome of a versatile chemolithoautotroph from expanding oceanic dead zones. Science. 2009;326(5952):578-82

30. Fujiwara Y, Takai K, Uematsu K, Tsuchida S, Hunt JC, Hashimoto J. Phylogenetic characterization of endosymbionts in three hydrothermal vent mussels: influence on host distributions. Mar Ecol Prog Ser. 2000:208:147-55.

31. Fisher CR, Childress JJ, Minnich E. Autotrophic carbon fixation by the chemoautotrophic symbionts of Riftia pachyptila. Biol Bull. 1989:177(3):372-85.

32. Van Dover $\mathrm{CL}$, Fry B. Stable isotopic compositions of hydrothermal vent organisms. Mar Biol. 1989;102(2):257-63.

33. Sunamura M, Higashi Y, Miyako C, Ishibashi Jl, Maruyama A. Two bacteria phylotypes are predominant in the Suiyo Seamount hydrothermal plume. Appl Environ Microbiol. 2004;70(2):1190-8

34. Labrenz M, Jost $\mathrm{G}$, Jürgens K. Distribution of abundant prokaryotic organisms in the water column of the central Baltic Sea with an oxicanoxic interface. Aq Micro Ecol. 2007;46(2):177-90.

35. Ulloa O, Canfield DE, DeLong EF, Letelier RM, Stewart FJ. Microbial oceanography of anoxic oxygen minimum zones. Proc Nat Acad Sci. 2012 109(40):15996-6003.

36. Glaubitz S, Kießlich K, Meeske C, Labrenz M, Jürgens K. SUP05 dominates the gammaproteobacterial sulfur oxidizer assemblages in pelagic redoxclines of the central Baltic and Black Seas. Appl Environ Microbiol. 2013;79(8):2767-76

37. Petersen JM, Wentrup C, Verna C, Knittel K, Dubilier N. Origins and evolutionary flexibility of chemosynthetic symbionts from deep-sea animals. Biol Bull. 2012;223(1):123-37.

38. McAuley PJ. Regulation of numbers of symbiotic Chlorella in digestive cells of green hydra. Endocyt Cell Res. 1985;2:179-90.

39. Mellas RE, Mcllroy SE, Fitt WK, Coffroth MA. Variation in symbiont uptake in the early ontogeny of the upside-down jellyfish, Cassiopea spp. J Exp Mar Bio Ecol. 2014:459:38-44.

40. Palincsar EE, Jones WR, Palincsar JS, Glogowski MA, Mastro JL. Bacterial aggregates within the epidermis of the sea anemone Aiptasia pallida. Biol Bull. 1989;177(1):130-40.

41. Schuett C, Doepke H, Grathoff A, Gedde M. Bacterial aggregates in the tentacles of the sea anemone Metridium senile. Helgoland Mar Res. 2007; 61(3):211-6

42. Preheim SP, Boucher $Y$, Wildschutte $H$, David LA, Veneziano D, Alm EJ, Polz MF. Metapopulation structure of Vibrionaceae among coastal marine invertebrates. Environ Microbiol. 2011;13(1):265-75.

43. Neave MJ, Apprill A, Ferrier-Pagès C, Voolstra CR. Diversity and function of prevalent symbiotic marine bacteria in the genus Endozoicomonas. App Microbio Biotech. 2016;100(19):8315-24

44. Schlichter D. The importance of dissolved organic compounds in sea water for the nutrition of Anemonia sulcate Pennant (Coelenterata). Proc Eur Mar Biol Symp. 1975;9:395-405.

45. Schlichter D. Adaptation of cnidarians for integumentary absorption of dissolved organic material. Rev Can Biol. 1980;39:259-82.

46. Shah $V$, Zhao X, Lundeen RA, Ingalls AE, Nicastro D, Morris RM. Morphological plasticity in a sulfur-oxidizing marine bacterium from the SUP05 clade enhances dark carbon fixation. mBio. 2019:10(3):e00216-9.

47. Marshall KT, Morris RM. Isolation of an aerobic sulfur oxidizer from the SUP05/Arctic96BD-19 clade. ISME J. 2013;7(2):452-5.

48. Ikuta T, Takaki Y, Nagai Y, Shimamura S, Tsuda M, Kawagucci S, Aoki Y, Inoue K, Teruya M, Satou K, Teruya K. Heterogeneous composition of key metabolic gene clusters in a vent mussel symbiont population. ISME J. 2016; 10(4):990-1001.

49. Kaplan IR, Emery KO, Rittenbebg SC. The distribution and isotopic abundance of sulphur in recent marine sediments off southern California. Geochim Cosmochim Acta. 1963;27(4):297-331.

50. Paris G, Sessions AL, Subhas AV, Adkins JF. MC-ICP-MS measurement of 834 S and $\triangle 33$ in small amounts of dissolved sulfate. Chem Geo. 2013;345:50-61. 
51. Fry B, Gest H, Hayes JM. Sulphur isotopic compositions of deep-sea hydrothermal vent animals. Nature. 1983;306(5938):51-2.

52. Sakai H, Des Marais DJ, Ueda A, Moore JG. Concentrations and isotope ratios of carbon, nitrogen and sulfur in ocean-floor basalts. Geochim Cosmochim Acta. 1984;48(12):2433-41.

53. Canfield DE. The evolution of the Earth surface sulfur reservoir. Am J Sci. 2004;304(10):839-61.

54. Chambers LA, Trudinger PA. Microbiological fractionation of stable sulfur isotopes: a review and critique. Geomicrobiol J. 1979;1(3):249-93.

55. Morse JW, Millero FJ, Cornwell JC, Rickard D. The chemistry of the hydrogen sulfide and iron sulfide systems in natural waters. Earth-Science Rev. 1987; 24(1):1-42.

56. Kim ES, Sakai H, Hashimoto J, Yanagisawa F, Ohta S. Sulfur isotopic ratios of hydrothermal vent-animals at Ogasawara Arc and Mid-Okinawa Troughevidence for microbial origin of hydrogen sulfide at low-temperature submarine hydrothermal areas. Geochem J. 1989;23(4):195-208.

57. Yamanaka T, Mizota C, Maki Y, Fujikura K, Chiba H. Sulfur isotope composition of soft tissues of deep-sea mussels, Bathymodiolus spp., in Japanese waters. Benthos Res. 2000;55(2):63-8.

58. Kantor RS, Wrighton KC, Handley KM, Sharon I, Hug LA, Castelle CJ, Thomas BC, Banfield JF. Small genomes and sparse metabolisms of sedimentassociated bacteria from four candidate phyla. MBio. 2013;4(5):e00708-13.

59. Harris JK, Kelley ST, Pace NR. New perspective on uncultured bacterial phylogenetic division OP11. Appl Environ Microbiol. 2004;70(2):845-9.

60. Wrighton KC, Thomas BC, Sharon I, Miller CS, Castelle CJ, VerBerkmoes NC, Wilkins MJ, Hettich RL, Lipton MS, Williams KH, Long PE. Fermentation, hydrogen, and sulfur metabolism in multiple uncultivated bacterial phyla. Science. 2012;337(6102):1661-5.

61. Nelson WC, Stegen JC. The reduced genomes of Parcubacteria (OD1) contain signatures of a symbiotic lifestyle. Front Microbiol. 2015;6:713.

62. Brown CT, Hug LA, Thomas BC, Sharon I, Castelle CJ, Singh A, Wilkins MJ, Wrighton KC, Williams KH, Banfield JF. Unusual biology across a group comprising more than 15\% of domain Bacteria. Nature. 2015;523(7559):208-11.

63. Goffredi SK, Tilic E, Mullin SW, Dawson KS, Keller A, Lee RW, Wu F, Levin LA Rouse GW, Cordes EE, Orphan VJ. Methanotrophic bacterial symbionts fuel dense populations of deep-sea feather duster worms (Sabellida, Annelida) and extend the spatial influence of methane seepage. Sci Adv. 2020;6(14):eaay8562.

64. Jones AM, Berkelmans R, van Oppen MJ, Mieog JC, Sinclair W. A community change in the algal endosymbionts of a scleractinian coral following a natural bleaching event: field evidence of acclimatization. Proc Royal Soc B. 2008;275(1641):1359-65.

65. Larson HK, Goffredi SK, Parra EL, Vargas O, Pinto-Tomas AA, McGlynn TP. Distribution and dietary regulation of an associated facultative Rhizobialesrelated bacterium in the omnivorous giant tropical ant, Paraponera clavata. Naturwissenschaften. 2014;101(5):397-406.

66. Doumenc D, Van-Praët M. Actinies abyssales d'un site hydrothermal du Pacifique oriental. Oceanologica Acta, Special issue. 1988.

67. Sanamyan NP, Sanamyan KE. Deep-water Actiniaria from East Pacific hydrothermal vents and cold seeps. Invert Zool. 2007:4(1):83-102.

68. Rogers AD, Tyler PA, Connelly DP, Copley JT, James R, Larter RD, Linse K, Mills RA, Garabato AN, Pancost RD, Pearce DA. The discovery of new deepsea hydrothermal vent communities in the Southern Ocean and implications for biogeography. PLoS Biol. 2012;10(1):e1001234.

69. Blazejak A, Kuever J, Erséus C, Amann R, Dubilier N. Phylogeny of $16 \mathrm{~S}$ rRNA, ribulose 1, 5-bisphosphate carboxylase/oxygenase, and adenosine 5'phosphosulfate reductase genes from gamma-and alphaproteobacterial symbionts in gutless marine worms (Oligochaeta) from Bermuda and the Bahamas. Appl Environ Microbiol. 2006;72(8):5527-36.

70. Caporaso JG, Lauber CL, Walters WA, Berg-Lyons D, Lozupone CA, Turnbaugh PJ, Fierer N, Knight R. Global patterns of 165 rRNA diversity at a depth of millions of sequences per sample. Proc Natl Acad Sci. 2011; 108(Suppl 1):4516-22.

71. Chen CA, Yu JK. Universal primers for amplification of mitochondrial small subunit ribosomal RNA-encoding gene in scleractinian corals. Mar Biotechnol. 2000;2(2):146-53.

72. Geller JB, Walton ED. Breaking up and getting together: evolution of symbiosis and cloning by fission in sea anemones (genus Anthopleura). Evolution. 2001;55(9):1781-94

73. Giribet G, Carranza S, Baguna J, Riutort M, Ribera C. First molecular evidence for the existence of a Tardigrada+ Arthropoda clade. Molec Bio Evol. 1996; $13(1): 76-84$
74. Gusmão LC, Grajales A, Rodríguez E. Sea anemones through X-rays: visualization of two species of Diadumene (Cnidaria, Actiniaria) using microCT. Amer Mus Novitates. 2018;2018(3907):1-47.

75. Katoh K, Standley DM. MAFFT multiple sequence alignment software version 7: improvements in performance and usability. Molec Biol Evol. 2013;30(4):772-80

76. Katoh K, Rozewicki J, Yamada KD. MAFFT online service: multiple sequence alignment, interactive sequence choice and visualization. Brief Bioinform. 2019:20(4):1160-6.

77. Guindon S, Gascuel O. A simple, fast, and accurate algorithm to estimate large phylogenies by maximum likelihood. Systematic Bio. 2003;52(5):696-704

78. Darriba D, Taboada GL, Doallo R, Posada D. jModelTest 2: more models, new heuristics and parallel computing. Nat Methods. 2012;9(8):772.

79. Miller MA, Pfeiffer W, Schwartz T. Creating the CIPRES Science Gateway for inference of large phylogenetic trees. Proc Gateway Computing Environments Workshop (GCE). 2010;1-8.

80. Kozlov AM, Darriba D, Flouri T, Morel B, Stamatakis A. RAxML-NG: a fast, scalable and user-friendly tool for maximum likelihood phylogenetic inference. Bioinformatics. 2019;35(21):4453-5.

81. Presnell JK, Schreibman MP. Humason's animal tissue techniques. Baltimore: Johns Hopkins University Press; 1997.

82. Weill R. Contribution à l'Étude des Cnidaires et de leurs NÉmatocystes. Paris: Les Presses Universitaires de France; 1934.

83. Carlgren O. A contribution to the knowledge of the structure and distribution of the cnidae in the Anthozoa. Kungliga Fysiografiska Sällskapets Handlingar. 1940;51:1-62.

84. Schmidt H. Die Nesselkapseln der Aktinien und ihre differentialdiagnostische Bedeutung. Helgoländer Meeresun. 1969;19(2):284-317.

85. Schmidt H. Die Nesselkapseln der Anthozoen und ihre Bedeutung für die phylogenetische Systematik. Helgoländer Meeresun. 1972;23(4):422-58.

86. Fautin DG. The importance of nematocysts to actiniarian taxonomy. Hessinger DA, Lenhoff HM. Biology of nematocysts. London: Academic Press; pp. 487-500.

87. Choi HM, Beck VA, Pierce NA. Next-generation in situ hybridization chain reaction: higher gain, lower cost, greater durability. ACS Nano. 2014;8(5): 4284-94.

88. Duperron S, Nadalig T, Caprais JC, Sibuet M, Fiala-Médioni A, Amann R, Dubilier N. Dual symbiosis in a Bathymodiolus sp. mussel from a methane seep on the Gabon continental margin (Southeast Atlantic): $16 \mathrm{~S}$ rRNA phylogeny and distribution of the symbionts in gills. Appl Environ Microbiol. 2005:71(4):1694-700.

\section{Publisher's Note}

Springer Nature remains neutral with regard to jurisdictional claims in published maps and institutional affiliations.
Ready to submit your research? Choose BMC and benefit from:

- fast, convenient online submission

- thorough peer review by experienced researchers in your field

- rapid publication on acceptance

- support for research data, including large and complex data types

- gold Open Access which fosters wider collaboration and increased citations

- maximum visibility for your research: over $100 \mathrm{M}$ website views per year

At BMC, research is always in progress.

Learn more biomedcentral.com/submissions 